\title{
Okul öncesi dönemdeki 5-6 yaş çocuklarının görsel okuryazarlık durumlarının ve dijital öğrenme içeriklerinin incelenmesi
}

\author{
Nagihan ALPAY \\ Muhammet Recep OKUR ${ }^{\mathrm{b}}$

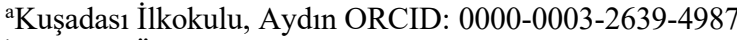 \\ bAnadolu Üniversitesi, Eskişehir ORCID: 0000-0003-2639-4987
}

\begin{abstract}
Özet
Türkiye'de uzaktan öğretim sürecine okul öncesi eğitimin de dahil olmasıyla beraber bu dönem çocuklarının görsel okuryazarlık durumları ile öğretimde kullanılan dijital öğrenme içeriklerinin ilişkisinin incelenmesi önem kazanmıştır. Bu çalışmanın amacı belirtilen ilişkinin alanyazında incelenmesi ve Eğitim Bilişim Ağı'ndaki (EBA) okul öncesi eğitimle ilgili dijital öğrenme içeriklerinin 5-6 yaş çocuklarının ilgi-güdü düzeylerini etkileme durumunun analiz edilmesidir. Bu bağlamda altı farklı öğrenme içeriğinin (dijital kitap, eğitici çizgi film, konu anlatımlı video, doküman, etkileşimli içerik, ses dosyası) 56 yaş grubu çocukların ilgi-güdü düzeylerine etkisi incelenmiştir. Araştırmanın sonucunda, çocukların ilgi ve güdülerini sağlamada en etkili öğrenme içeriğinin etkileşimli içerikler olduğu; konu anlatımlı video, eğitici çizgi film, ses dosyası ve dijital kitap içeriklerinin çocukların ilgi ve güdülerini sağlamada etkisinin yüksek olduğu; dokümanlarla öğrenen çocukların ilgi ve güdülerinin ise düşük olduğu belirlenmiştir.
\end{abstract}

Anahtar Sözcükler: Okul Öncesi Eğitim, Uzaktan Eğitim, Dijital İçerik.

\section{Analysis of the digital learning content and the visual literacy status of 5-6-year- old preschool children}

\begin{abstract}
With the inclusion of pre-school education in the distance education process in Turkey, it has become important to examine the relationship between the visual literacy status of the children of this period and the digital learning content used in education. The aim of this study is to examine the mentioned relationship in the literature and to analyze the effect of the digital learning contents related to preschool education in the Education Information Network (EBA) on the interestmotivation levels of 5-6-year-old children. In this context, the effects of six different learning content (digital book, educational cartoon, video with lecture, document, interactive content, audio file) on the interest-motivation levels of 5-6year-old children were examined. The results of the study showed that the most effective learning content in providing children's interests and motivations was interactive content. While interests and motivations of children learning with video, educational cartoons, audio files, and digital book contents were high, it was determined that the interests and motivations of children learning with documents were low.
\end{abstract}

Keywords: Preschool Education, Distance Education, Digital Content.

\section{Kaynak Gösterme}

Alpay, N. ve Okur, M. R. (2021). Okul öncesi dönemdeki 5-6 yaş çocuklarının görsel okuryazarlık durumlarının ve dijital öğrenme içeriklerinin incelenmesi. Açıköğretim Uygulamalarl ve Araştırmaları Dergisi (AUAd), 7(3), 1-34. https://doi.org/10.51948/auad.951885 


\section{Giriş}

2020 yılının Mart ayında ülkemizde ilk Covid-19 vakasının görülmesi sebebiyle Milli Eğitim Bakanlığı tarafından uygulanmaya başlanan acil durum eğitim politikası kapsamında okul öncesi eğitim kurumlarında yüz yüze eğitime ara verilmiştir. 1 Haziran 2020'de Bakanlık, okul öncesi eğitimin kademeli olarak yüz yüze yapılması için izin vermiş fakat takip eden dönemde vaka sayılarının değişiminden etkilenen idari kararlar çerçevesinde yeniden sınırlandırma getirmiştir (MEB, 2020).

Okul öncesi yüz yüze öğretim sürecinde eğitim kurumlarında teknoloji destekli aletlerin kullanımının ve dijital öğrenme içeriklerinin sunumunun eğitimciler tarafından yapılmış olması, çocukların bu uygulamalar ve içerikler hakkında bilgi kazanmasını sağlamıştır. Başka bir deyişle küçük çocukların görsel okuryazarlıklarının aktif hale geldiği öğrenme ortamları artık sadece sınıfları değil dijital ekranların gösterdiği sayısız platformu kapsar hale gelmiştir. Ayrıca uzaktan öğretim sürecinde dijital içeriklerin ve bilgisayarların kontrol ve yönetimi her ne kadar ebeveyn destekli olsa da- çocukların sorumluluğu haline gelmiştir. Bu durum “çocuk-dijital öğrenme içeriği” arasındaki etkileşimi yoğunlaştırmış ve çocukların öğrenme tercihlerinin daha kolay gözlenebilir bir hal almasını sağlamıştır.

\section{Araştırma Sorunsalı}

Türkiye'de Milli Eğitim Bakanlığı tarafından Covid-19 Pandemi Süreci öncesinde ve kriz yaklaşımı olmaksızın yürütülmekte olan projeler sayesinde bilgi iletişim teknolojileri yüz yüze öğretim sınıflarına girmiş ve kullanılmaya başlanmıştır. 2012 yılında EBA öğrenme platformunun örgün eğitimde aktif şekilde yerini alması, eğitim politikamızda açık ve uzaktan öğrenme sürecine verilen önemin ve rolün en güçlü göstergesidir. Pandemi sürecinde eğitim-öğretim politikamızın acil durum eylem planlarını başarıyla uygulamaya geçirebilmesi, Milli Eğitim Bakanlığg tarafından gerçekleştirilen bu proaktif çalışmalar ve uygulamalar sayesinde mümkün olmuştur.

Okul öncesi uzaktan öğretim sürecinde kullanılan dijital öğrenme kaynaklarının kolaylık, yarar, güdü, dikkat ve tercih gibi faktörler çerçevesinde değerlendirilmesi ve bu durumla ilgili bilimsel araştırmaların yapılması; uzaktan öğretim sürecinde kaliteyi, verimi ve gelişimi artırma probleminin çözümü için gerekli bir hal almıştır. Her türlü eğitim krizinin yönetimini başarıyla gerçekleştirebilmek için yapılacak hazırlıkların ve planlamaların bilimsel bulgular 1şığında gerçekleştirilmesi, gelecekte daha yararlı ve etkili acil durum 
politikalarının uygulanabilmesini sağlayacaktır. Bu kapsamda araştırma sorunsalı şu şekilde belirlenmiştir:

“Okul öncesi dönemdeki 5-6 yaş çocuklarının gelişim özellikleri ile doğrudan ilişkili olan görsel okuryazarlık durumları dikkate alınarak bu yaş çocuklarının öğrenme süreçlerindeki güdü-ilgi düzeylerini artıran dijital öğrenme içerikleri nelerdir?’

Araştırma sorunsalının alt problemleri şunlardır:

1. Okul öncesi dönemdeki 5-6 yaş çocuklarının görsel okuryazarlık durumlarını etkileyen bileşenler nelerdir?

2. Okul öncesi uzaktan eğitim sürecinde kullanılan dijital öğrenme içeriklerinin yapısı nasil olmalıdır?

3. Okul öncesi uzaktan eğitim sürecinde kullanılan dijital öğrenme içeriklerinin türleri, çocukların ilgi ve güdülerini nasıl etkiler?

Alt problemlerle ilişkili olarak 2012 yılından itibaren Milli Eğitim Bakanlığ bünyesinde hizmet veren Eğitim Bilişim Ağı’ nda kullanılan altı farklı türde dijital öğrenme içeriği belirlenmiş ve bu içeriklerin çocukların öğrenme süreçlerinde ilgi-güdüyü sağlama düzeyleri araştırılmıştır:

1. Dijital Kitap

2. Eğitici Çizgi Film

3. Konu Anlatımlı Video

4. Doküman

5. Etkileşimli İçerik

6. Ses Dosyas 1

Nitel eylem türündeki araştırmanın katılımcıları Aydın ili Kuşadası ilçesinde 20202021 eğitim-öğretim yılında okul öncesi eğitim alan 5-6 yaş grubu öğrenciler arasından seçilirken amaçlı örnekleme yöntemi kullanılmıştır. Bu sebeple araştırma katılımcı çocukların velilerinin gönüllü olarak cevapladıkları anket soruları, ilgili eğitim-öğretim dönemi, verilen toplandığı üç haftalık süre alanyazında erişilen kaynaklar ile sınırlıdır.

\section{İlgili Alanyazın}

Pandemi süreci, oyun çocuğu olarak adlandırabileceğimiz okul öncesi dönem çocuklarının gelişimlerini olumsuz yönde tehdit etmektedir. İnsan gelişiminin bu ilk kritik dönemindeki çocukların sadece fiziksel sağlıkları değil psikolojik sağlıkları da önemsenmelidir. Sevdiğini kaybeden, evde hasta birey bulunması sebebiyle aile fertlerinden uzak kalan, hastalığa yakalanan küçük çocuklar, evde kaldıkları süre boyunca psikolojik 
şiddete maruz kalmış olacaklardır. Bu sebeple okul öncesi çocuklarına yönelik uzaktan eğitim faaliyetlerinin planlanması ve uygulanması yoğun hassasiyet, kontrol, takip ve dikkat gerektirir (İnan, 2020, s.841).

Tasarımı ve işletilmesi Milli Eğitim Bakanlığına bağlı Yenilik ve Eğitim Teknolojileri Genel Müdürlüğü tarafından gerçekleştirilen ve kısaca EBA olarak adlandırılan ve Eğitim Bilişim Ağı, 2014 yılının Nisan ayında eğitim-öğretim dünyasında aktif olarak yerini almıştır. EBA, öğretmen ve öğrencilerin teknolojik gelişime uyumlu ve paralel şekilde eğitsel e-içerik üretebilmelerine ve bu içerikleri paylaşabilmelerine imkan sağlayan sosyal bir eğitim platformu olarak kullanılmaktadır. Bu dijital öğrenme ortamı sayesinde fırsat eşitliği ilkesi sağlanmış ve e-ders projesi uygulamaya geçirilmiştir (Şenyurt, 2015, s.229).

\section{Çalışmanın Kuramsal Temelleri}

$\mathrm{Bu}$ çalışma okul öncesi dönem çocuklarının öğretiminde kullanılan etkili görsel içeriklerin dijital ortamdaki yeni tasarımlarına uyarlanmasında dikkat edilmesi gereken önemli unsurları belirleme ihtiyacına odaklanmıştır. Araştırmada okul öncesi dönemdeki 5-6 yaş çocuklarının görsel okuryazarlık durumlarının alanyazın taraması ile incelenmesi ve uzaktan öğretim sürecinde kullanılan farklı dijital öğrenme içeriklerinin belirtilen yaş grubundaki çocuklar tarafından tercih edilme durumlarının “ilgi ve güdü” ölçütlerine göre değerlendirilmesi amaçlanmıştır. Bu bağlamda çalışmanın kuramsal temelini oluşturan görsel okuryazarlık kavramı, 5-6 yaş çocuklarının gelişim özellikleri dikkate alınarak eleştirel görsel okuryazarlık yaklaşımı çerçevesinde incelenmiş ve araştırma soruları bu yaklaşım çerçevesinde değerlendirilmiştir.

\section{Çalışmayla Doğrudan İlişkili Araştırmalar}

$\mathrm{Bu}$ bölümde araştırmanın gözlem grubunu oluşturan ve okul öncesi uzaktan eğitim sürecine aktif olarak katılmış olan 5-6 yaş çocuklarının görsel okuryazarlık düzeyleri ile ilgili birincil bilgi ve bulgulara yer veren araştırmalar incelenmiştir.

Okul öncesi dönem; sembolik bilginin gelişimi, görsellerin anlamlandırılması, görsellerin taklit edilmesi ve görsellerle duygu ve düşüncelerin ifade edilmesi gibi "görsel algı"nın bireyin gelişiminde en önemli yansımalarının yoğun olarak görüldüğü kritik bir gelişim dönemidir. Çocuğun oluşturduğu her görsel unsur, eğitimcilere onun gelişim süreci ve iç dünyası hakkında bilgi verir. Bu görsel unsurları yorumlayarak öğrenme faaliyetlerini 
düzenleyecek olan eğitimcinin okul öncesi dönem çocuğunun görsel alg1 ve görsel okuryazarlık süreci hakkında yeterli bilgiye ve donanıma sahip olması oldukça önemlidir.

Dil; yazı sembolleri, sesler, jestler ve beden duruşu gibi sözel ya da sözel olmayan ifade biçimlerini kullanarak duygu ve düşünceleri karşıdaki kişiye anlamlı bir iletişim kurma amacıyla iletmektir. Okul öncesi dönem çocuklarında dilin uygulaması, sözel ifadelerin çocukların sosyal yaşantılarında yerinde ve anlamlı biçimde kullanılması olarak gözlenir (Güven ve Bal, 2000, s.13-14). Bu uygunluk ve yerindeliğin çocuk tarafindan kavranması ise dilin görsel unsurlarının doğru ve tekrarlı olarak okunması, algılanması ve deneyimlenmesi ile gerçekleşir. Annesinin isimlerini söyleyerek kendisine gösterdiği nesneleri öğrenen, diğer çocuklarla oyunlarında gözlem yaparak oyun kurallarını anlayan, yeni karşılaştığı bir kavramı hikâyenin resimleri ile yorumlayan, toplumsal kuralları yakın çevresini görerek-okuyarak kavrayan 0-6 yaş çocukları, "görseller - nesne, olay, kelime, kavramlar" arasında sürekli olarak bağlantılar kurarak dil gelişimini ilerletir. Bu sebeple okul öncesi dönem çocuklarının dil gelişimini pekiştirmek için onlara görsel algı düzeylerine uygun, ilgi ve güdülerini harekete geçirecek zengin görsel okuma etkinlikleri sunmak gerekmektedir.

Alıcı dil gelişimi bilişsel gelişimle paralellik göstermektedir. Okul öncesi dönemde çocuğun sosyal-duygusal, bilişsel, dilsel, psikomotor ve özbakım becerilerinin gelişimi ona sunulacak görsel içeriklerin zengin, uygun ve amaçsal olmasıyla sağlanacaktır. 2013 yılında revize edilen MEB Okul Öncesi Eğitim Programının içeriğinde yer alan kazanımların bu bağlamda görsel içeriklerle ve görsel okumayla ilişkisi incelendiğinde "görsel materyalleri ve izlediklerini okuma/inceleme/açıklama, görsel materyallerle olay / hikaye / kompozisyon oluşturma, görsel algı yeterliklerine ulaşma (el-göz koordinasyonu, şekil ve zemin algısı, mekanla ilgili ilişkiler ve konum algısı) hedeflerinin görsel okuryazarlığın temelini oluşturan becerilerle ilgili olduğu görülür (Özkubat, 2015, s.27).

MEB Okul Öncesi Eğitim Programında yer alan kazanım ve göstergeler ile görsel okuryazarlık arasında sözcüksel ilişki kurulduğunda şu tablodaki kazanımlar öne çıkar: 


\begin{tabular}{|c|c|}
\hline \multicolumn{2}{|c|}{$\begin{array}{l}\text { Tablo } 1 \\
\text { MEB Okul Öncesi Eğitim Programında yer alan ve görsel okuryazarlıkla ilişkili olan } \\
\text { kazanım ve göstergeler }\end{array}$} \\
\hline \multirow[t]{6}{*}{ Bilişsel Gelişim Alanı } & Kazanım 5: Nesne veya varlıkları gözlemler. \\
\hline & Kazanım 10. Mekânda konumla ilgili yönergeleri uygular. \\
\hline & Kazanım 12. Geometrik ssekilleri tanır. \\
\hline & Kazanım 13. Günlük yaşamda kullanılan sembolleri tanır. \\
\hline & Kazanım 15. Parça-bütüin ilişkisini kavrar. \\
\hline & Kazanım 20. Nesne/sembollerle grafik hazırlar. \\
\hline \multirow[t]{4}{*}{ Dil Gelişimi Alanı } & Kazanım 7. Dinlediklerinin/izlediklerinin anlamını kavrar. \\
\hline & Kazanım 10. Görsel materyalleri okur. \\
\hline & Kazanım 11. Okuma farkındalığı gösterir. \\
\hline & Kazanım 12.Yazı farkındalığı gösterir. \\
\hline Sosyal ve Duygusal Gelişim & Kazanım 13. Estetik değerleri korur. \\
\hline
\end{tabular}

Tablo 1'deki kazanım ve göstergelerin görsel okuryazarlıkla ilişkisi sadece sözcüksel ve yazımla ilgilidir. Programdaki diğer kazanımların görsel okuryazarlıkla ilişkili olmadığını ya da aralarındaki ilişkinin düşük yoğunlukta olduğunu varsaymak hiçbir zaman mümkün değildir. Bilişsel gelişimle ilgili "nesneleri sayma, eşleştirme, gruplama, özelliklerine göre karşılaştırma" gibi hedefler, çocuğun görsel algısı ve okuduğu görsel olaylar / materyaller ile doğrudan ilgilidir. Görsel okuma (gözlemleme, algılama, yorumlama, dikkat) gerçekleşmeden çocuğun bahsedilen becerilere sahip olması oldukça zordur.

Görsel algılama; görsel uyaranlara cevapların oluşturulduğu, bireyin dış dünyada olup biteni anladığı, kendi bedeni ve dış dünya arasındaki bağlantıyı kurduğu, dinamik ve bireyin tüm duyularını birleştiren bir süreçtir. Bireyin sahip olduğu toplam duyu reseptörlerinin \%70'inin gözde bulunuyor olduğu gerçeği, görsel algılamanın çocuğun dış dünyayı algılamasındaki önemini göstermektedir. Görsel algı hakkındaki farklı referanslardan en önemlisi erken çocukluk döneminde görsel algının gelişimsel bir süreç içinde olmasıdır. $\mathrm{Bu}$ gelişimsel süreç görsel uyaranları gözlemleyerek ve deneyimleyerek öğrenmeyi içerir. Ayrıca birçok araştırmacı görsel algılama gelişimi ile okuma-yazma benzeri görevler arasında bir ilgileşim olduğunu kabul ederler (Kramer ve Hinojosa, 2010; Akt. Ayhan ve diğerleri, 2015, s.832).

5-6 yaş çocuklarına yönelik eğitim sürecinde yararlanılacak görsel içeriklerdeki resimler, çeşitli işlevleri karşılamaktadır. Çocuğun dinlerken sıkılabileceği tasvirler onun ilgisini daha çok çeken resimler aracılığıyla anlatılabilir. Tanımlama içeren karmaşık cümleler, resim kullanılarak sadeleştirilir, somutlaştırılır ve böylelikle çocukların anlamlı bir imge oluşturmaları sağlanır. Çocuklar resimleri hikayeyi somutlaştırma ve günlük yaşamdaki 
modellerle ilişkilendirme yapma amaçlarıyla okurlar. Bu görsel okumanın gerçekliği ve kendisine verilen bilgiyle tutarlı olması çok önemlidir. Örneğin hikayede bahsi geçen çocuk sarı saçlı ve mavi gözlüyse, resimde çizilen çocuk yeşil gözlü ve kumral olamaz (Bilgin, 2011, s.47).

Okul öncesi eğitimde görsel okuryazarlık becerilerinin geliştirilmesindeki en önemli araç hikaye resimleridir. Çocuğa öğretilmek istenen her konu ve verilmesi amaçlanan her değer bir olay kurgusu ve neden-sonuç ilişkisi içerisinde verilir. En etkili materyallerden biri olan hikaye kartları, çocukların ilgisini çekmek için özel boyut ve renkler kullanılarak ve çocuğun gelişim özelliklerine uygun biçimde hazırlanır. Öğretmen sırayla kartları göstererek hikayeyi anlatır ve kartlardaki görsele göz kontağının sürekli olması amacıyla metin kartın arkasındadır. Yazılı metin sadece öğretmen tarafından görülür ve resmin içerisinde yer almadığı için çocuğun dikkati dağılmaz. Çocuk resimleri teker teker incelediği için sıradaki resmin ne olduğunu merak eder ve ilgisi devam eder. Diğer hikaye anlatım tekniklerindeki (pazen tahta, televizyon şeridi, kukla sahnesi, slayt, tepegöz, elektronik ekran) görseller de aynı mantıkla tasarlanır (Varol, Ala ve Eti, 2020, s.27).

Dijital hikayeler; geleneksel hikayeleri, teknolojik uygulamaları ve çoklu ortamları kullanarak bilgisayar ortamında revize etmek yoluyla oluşturulan yeni biçimli öğrenme içerikleri olarak tanımlanabilir. Hikaye metnine ses, müzik, animasyon ve video gibi farklı öğeler eklenerek oluşturulan yeni bir formdur (Ciğerci, 2005, s.33).

Okul öncesi eğitimde uzaktan eğitim materyali olarak kullanılan dijital hikayeler, çocukların yeni teknolojik döneme uyum sağlayabilmelerini, bu dönemin gerekli kıldığ becerileri geliştirebilmelerini ve öğrenme heveslerini arttırmayı sağlayan yeni bir yöntem olarak kullanılmaktadır (Morgan, 2014). Dijital hikayeler ile ses-görüntü-animasyon birleştirilir ve çocuğa hikayenin metni iletilir. Böylelikle hem görme hem işitme duyusu öğrenme sürecine katılarak iletişim kanal sayısı artırılmış ve öğrenmede verim sağlanmış olur (Akt. Türe Köse, 2019).

Bull ve Kajder (2005, s.47), etkili dijital hikayelerin oluşum sürecindeki yedi önemli öğeyi Joe Lambert'in araştırmaları doğrultusunda şu şekilde belirlemişlerdir:

1. Bakış açısı (a point of view): Dijital hikayelerin deneyim ve yaşantılarla ilişkilendirilmesi ve yazarın kişisel ifadesi ile vermek istediği mesajı iletmesidir. Yazar uzak bir konu hakkındaki gerçekleri ortaya çıkarma amacındadır. 
2. Dramatik soru (a dramatic question): Seyircinin dikkatini aktif tutan bir hikaye, hikayenin sonunda çözülen ilgi çekici bir soruya sahiptir. Hikayeci, böylelikle okuyucuyu/dinleyiciyi takibe ve bağlılığa yönlendirir.

3. Duygusal içerik (emotional content): En etkili dijital hikayeler seyircilerde kahkaha, üzüntü ya da eğlenme gibi duygusal tepkiler oluşturan hikayelerdir. Dijital hikayelerin sahip olması gereken duygusal içeriğin geri dönüşü, yazarın emeğine karşılık muazzam bir ödül durumundadır.

4. Ekonomi (economy): Dijital hikayenin süresinin hikayenin hazırlık aşamasına etkisi olarak düşünülen ekonomi faktörü bağlamında ideal olan bir hikayenin 2-5 dakika sürecek şekilde hazırlanmasıdır. Böylelikle okuyucunun (izleyici / dinleyici) sıkılması önlenecek, gereksiz ayrıntılardan kaçınılacaktır. Hikayede kullanılan resim, müzik, video, efekt, grafik, fotoğraf gibi ses ve görsellerin sayısı da ekonomi öğesiyle ilişkilidir.

5. Tempo (pacing): Hikayenin akışındaki ritim, enerji ve tempo dinleyicinin dikkatini çekmek ve monotonluğu önlemek için önemlidir. Ekonomi ve tempo arasında önemli bir etkileşim vardır. Acemi hikaye anlatıcıları genellikle kısa bir senaryoyu iki dakikada -olabildiğince hızlı- anlatırlar ve bu yaklaşım temponun duraklama ya da hızlanma ile değişimine izin vermez. Zaman sınırlamasının karşıtı durumundaki tempo, gerektiğinde hikayenin geri çekilmesi veya ileriye doğru hızlanması anlamına gelir.

6. Etkili Seslendirme (the gift of your voice): Anlatıcının sesinin perdesi, tonlaması ve tınısı, anlam ve mesajı çok kişisel bir şekilde okuyucuya aktarır. Hikayeyi anlatmak için yazarın kendi sesini kullanması, dijital bir hikayenin etkililiğine katkıda bulunan en temel unsurlardan biridir.

7. Müziğin Eşliğgi (an accompanying soundtrack): Müzik profesyonel sinemanın önemli bir unsurudur. Uygun kullanılan müzik, anlatıya karmaşıklık ve derinlik katarak eşlik eder; böylelikle hikayeyi geliştirebilir ve altını çizebilir. Ayrıca bazı durumlarda yalnızca sese dayanan dijital hikayeler öğrenciler üzerinde oldukça etkileyici olmaktadir.

Çocuklara yönelik olarak planlanan her türlü dijital içerik bir konu ya da mesaj içerir. Öykü, senaryo veya kurguyla oluşturulan içeriğin konusu, çocuk edebiyatının ilke ve değerleri 1şığında kimlik kazanmalıdır. Sever (2003, s.110-131) çocuklara yönelik içeriklerin konusuyla ilgili önemli öğeleri şöyle yorumlamıştır: 
- Çocuk edebiyatında konu alanı çocukların gelişim dönemlerine göre artarak zenginleşir.

- Okul öncesi dönem çocuğu için eğitimde kullanılacak içerikler mutlaka bir ileti içermelidir.

- İçeriklerde kullanılan dil ve anlatım çocuğun yaş seviyesine ve gelişim özelliklerine uygun olmalidir.

- Konu / içerik, çocuk gerçekliğini önemseyen, onların beklentilerine yanıt veren, neden-sonuç ilişkilerini açıklayan yapıda olmalıdır.

- Çocukların hayal güçlerini ve yaratıcılıklarını desteklemeli ve onlara özgür düşünebilecekleri bir dünya sunmalıdır.

- Konu / içerik, "sevgi” kaynağından beslenmelidir. Değerler eğitimine uygun kazanımlar hedeflenmelidir.

- Çocukların ve diğer canlıların bireysel farklılıklarını kavratıcı ve bu farklılıklara saygıyı benimsetici nitelikte olmalıdır.

- Çocukların kendilerini tanımalarına ve benlik saygısı geliştirmelerine destek vermelidir.

- Çocukları sağlıklı, güvenli ve olumlu sosyal ilişkiler içindeki bir yaşamın nasıl sürdürüleceği konusunda bilgilendirmelidir.

- Çocukları, kendi duygu ve düşüncelerini ifade etmeye teşvik ederek iletişim becerilerini geliştirmelidir.

- Olay / çatışma çerçevesinde gelişen içerikler, çocuklara problem çözme becerileri kazandırmalıdır.

- Abartılmış merak oluşturulmamalı; çocuğun heyecan ve endişelerinin sürekli olarak yoğunlaşmamasına ve duygusal durumunun dengede kalmasına dikkat edilmelidir.

- Öyküdeki düğümün bir rastlantıya ya da şansa dayanarak çözüldüğü kurgulardan kaçınılmalı ve inandırıcılığın azalması engellenmelidir.

- Yoğun duygusallıktan kaçınılmalı, duygunun aşırı ölçüde zorlandığı ve kullanılmaya çalışıldığı yaşam durumları konu olarak işlenmemelidir.

- İçerikler dikkat çeken bir girişle başlatılmalı (merak uyandıran bir soru, parmak oyunu, ilginç bir resim ya da diyalog, tekerleme, beklenmedik bir yönerge vb); girişgelişme-sonuç döngüsüne uygun oluşturulmalıdır. 
- Okul öncesinde eğitim içeriklerinde kullanılan deyim, mecaz ve diğer soyut kavramlar somutlaştırılarak ve örneklendirilerek sunulmalıdır.

Okul öncesi eğitimde çocukların kitle iletişim araçlarının yayınları, görsel medya ve uzaktan öğretim sürecinde yoğun olarak karşılaştıkları içerik türü, videolardır. Videolar okul öncesi dönemde konu ve içerik bakımından "çocuk edebiyatı" alanındaki referanslar ile şekillenirken görsel özellikleri de bu etkileşime göre biçimlendirilmelidir. Çocuklara sunulan her türlü görsel çocukların ilgisini aktif tutan, hoşlarına giden ve eğitici niteliğe sahip yapıda olmalıdır. Videolardaki renk, karakterler, süre, çizim tarzı, çözünürlük, hareket akışındaki tempo, efektler, etkileşimli uygulamalar, müzik ve seslendirme gibi birçok öğe, çocukların gelişim düzeyine uygun yapıda ve onlardan alınan geri dönüşler doğrultusunda biçimlendirilmelidir.

Televizyon yayınları kolay ulaşılır olması nedeniyle küçük çocukların en fazla izlediği içerikler olan çizgi filmleri sunması nedeniyle onların bilgi sahibi olmalarında ve davranış kazanımlarında en etkili kanal olarak kabul edilmelidir. Çok sayıda araştırma, okul öncesi dönemdeki çocukların şiddet içerikli davranışlar gösteren çizgi film karakterlerinden etkilenerek oyunlarında ve akranları ya da yetişkinlerle etkileşimlerinde artan saldırganlık davranışları gösterdiğini ortaya çıkarmıştır (Bandura, Ross \& Ross, 1963a, 1963b; Akt. Peters ve Blumberg, 2002, s.144). Bu sebeple bu dönem çocuklarına sunulan hareketli görsellerin şiddet ve tehlikeli davranışlar içermemesi gerekmektedir.

Bayır ve Günşen (2017, s.747), temel eğitime hazırlık döneminde olan okul öncesi çocuklarına yönelik çizgi film ve videoların, toplumun ve çocukların geleceği için bir yatırım olması amacıyla "fen eğitimi” ne ağırlık verilmesi görüşündedir. Bu dönemdeki çocukların yoğun olarak çevresini anlama ve tanıma, gözlem yapma, güçlü bir merak duygusuyla hareket etme ve çevreyle ilişkili sorular sorma eğilimi ve çabası içerisinde olmaları, fen eğitimine başlamak için çok iyi bir fırsattır. Çizgi filmlerde bilimsel ifadelere yer verilmesi ve bilimsel kavramların çocukların gelişim düzeylerine uygun olarak açıklanması, çocuklarda bilimsel bakış açısının oluşması için oldukça etkili ve önemlidir.

Çocuklara yönelik videoların biçimsel özellikleri, içerik ve işlev ile yoğun bir etkileşim içindedir. $\mathrm{Bu}$ bağlamda filmin gösteriminde eşlik eden yan etmenler olarak tanımlayabileceğimiz biçimsel özellikler, içeriği ya da içerikteki eylem dizgisini etkilememekte, sadece eylemlerin az ya da yoğun olarak vurgulanması işlevini gerçekleştirmektedir. Video seyrederken çocukların dikkati, çocuk sesi, ilginç sesler, ses 
efektleri, beklenmedik değişiklikler ve görsel hareketlilik gibi biçimsel özelliklerle olumlu bir ilişki içerisindedir. Ayrıca ses unsuru ile kıyaslandığında görsel özelliklerin daha etkili olduğu araştırmalarla kanıtlanmıştır (Pezdek ve Stevens, 1984; Akt. Öcel, 2012, s.382).

Çocuklar ve yetişkinler, farklı sosyal ortamlarda iletişim kurarken ve bilgi edinirken çeşitli öğrenme biçimleri kullanırlar. Uzaktan öğrenme çerçevesinde sözlü ya da yazılı dil gibi tek bir kanala odaklanmak yerine bilgi aktarımı için videoyu kullanmak, sınıf etkileşiminde çok modlu bir dinamizmi ortaya çıkarmaktadır (Flewitt, 2006, s.29). Farklı dijital bilgi kaynaklarını kullanma ya da kaynak-bilgi arasındaki bağlantı kurma becerilerine henüz sahip olmayan okul öncesi dönemdeki çocuklarla gerçekleştirilen öğretim süreci, Türkiye'de EBA üzerinden gerçekleştirilmektedir. EBA ile sunulan uzaktan öğrenme içeriklerini şu başlıklar altında incelemek mümkündür:

EBA dijital kitap: Okul öncesi öğrencilere sunulan dijital kitaplar ve dergiler, sayfaların tıklanarak ya da sürüklenerek değiştirildiği sesli materyallerdir.

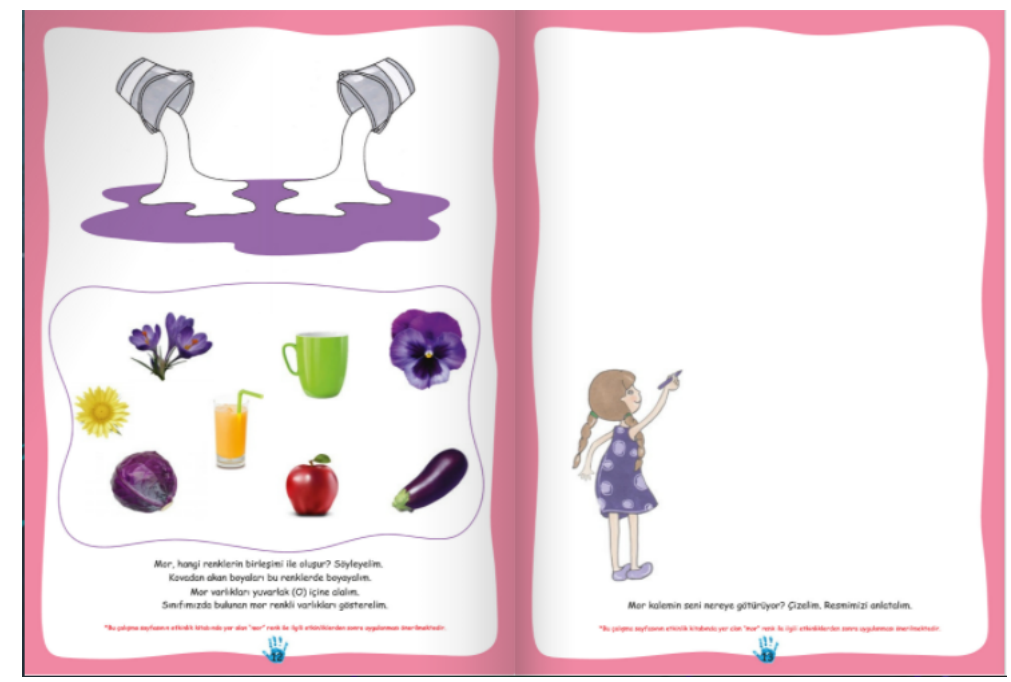

Görsel 1. EBA, El Ele okul öncesi eğitim kitab1- 2

EBA eğitici çizgi film: Okul öncesi öğrencilere sunulan eğitici çizgi filmlerin yüksek çözünürlük, çok ve canlı renklilik, ideal ses-hareket senkronu ve tempo gibi biçimsel özellikleri, sevimli karakter seçimi gibi göze çarpan biçimsel özellikleri, bu dönem çocuklarının gelişim özellikleri dikkate alınarak uygulanmış öğelerdir. Hem eğitici hem de bilgilendirici yapıdadırlar. 


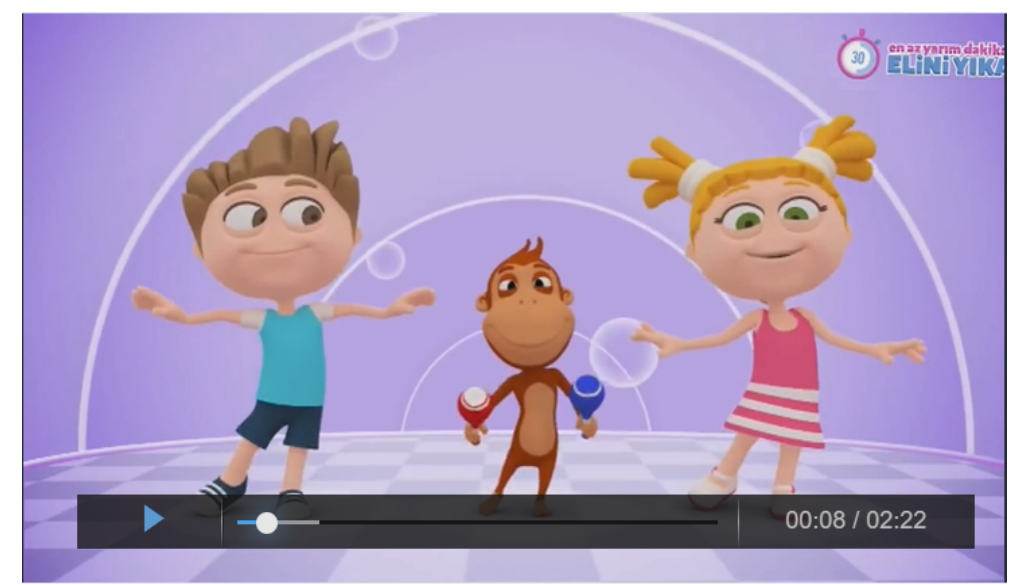

Görsel 2. EBA çizgi film, Kukuli en az yarım dakika elini yıka.

EBA eğitici konu videosu: Okul öncesi öğrencilere sunulan eğitici konu videoları genellikle çizgi-animasyon biçimindedir. Konu videolarında genellikle kavramlar, nedensonuç ilişkileri, toplumsal kurallar, sağlıklı ve güvenli yaşam bilinci gibi okul öncesi eğitim programında yer alan kazanımlara yönelik konular işlenir.

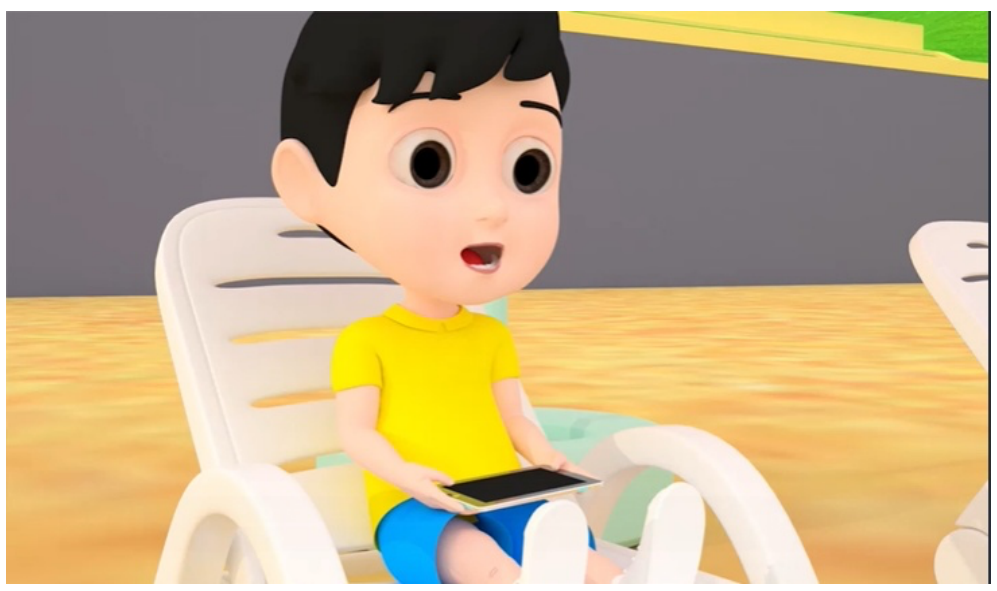

Görsel 3. EBA eğitici video, internette geçirilen aşırı zaman, okul öncesi

EBA doküman (Etkinlikler): Okul öncesi eğitimle ilgili EBA dokümanlar, çocuklara yönelik olarak hem öğretmenlerin hem de ebeveynlerin uygulayabileceği etkinlikleri sunar. Yönergelerin verildiği ve gerçek yaşam uygulamalarının hedeflendiği bu enformasyonlar okul öncesi dönem çocuğunun eğitiminde oldukça yararlıdır. 


\section{ETKİNLIKK 4}

\section{Uygulama Zamanı (20 dk)}

Malzemeler: Ek-8 (Durum Kartlari)

\section{Yönerge:}

1. Katılımcilar beş gruba ayrilır.

2. Gruplara, her gruba bir kart gelecek şekilde çeşitli durumlar ve sorular içeren kartlar dağttılacağı anlatılır.

3. 10 dakika içinde kartta verilen durumu değerlendirmeleri ve o durum için bir veli katılımı planı oluşturmaları istenir.

4. Her grubun bir sözcü belirlemesi istenir ve 10 dakikanin sonunda sözcünün, hazırlanan planı büyük gruba anlatacağı söylenir. Planı hazırlarken, olabildiğince farklı etkinlik türlerinin kullanılmasının önemine dikkat çekilir.

5. Her gruba EK-8' deki kartlardan biri verilir.

6. Her grubun çalışmasını sözcüler aracilığıyla büyük gruba aktarması sağlanır. Diğer gruplardan, sunumlara varsa eklemelerini yapmalan istenir. Gerekirse eğitimci tarafindan da sunumlara ekleme yapilabilir.

7. Sunumların bitiminde gruplara teșekkür edilerek oturum tamamlanır.

Eğitimciye Not: Etkinlik sırasında grupların dolaşılması ve her grubun yönergeyi anladığından emin olunması önemlidir. Grupların soruları varsa cevaplanmalıdır. Aynı zamanda süreyi etkili kullanmaları için gruplara hızlanmaları için "3 dakikamız var" şeklinde minik hatırlatmalar yapılarak çalışmayı zamanında tamamlamaları teşvik edilir.

Görsel 4. EBA dokümanlar; etkinlik 4.

EBA etkileşimli içerik: Okul öncesi öğrencilere sunulan etkileşimli içerikler, onlara boyama yapma, oyun oynama, yapboz yapma gibi aktiviteler sunarken el-göz koordinasyonlarını geliştirir. Kazanımların oyunlaştırılarak sunulduğu eğlenceli etkinlikler olan etkileşimli içerikler, çocuklarda yüksek güdü ve ilgi oluşturması yönüyle öğretim sürecinde çok etkilidirler. 


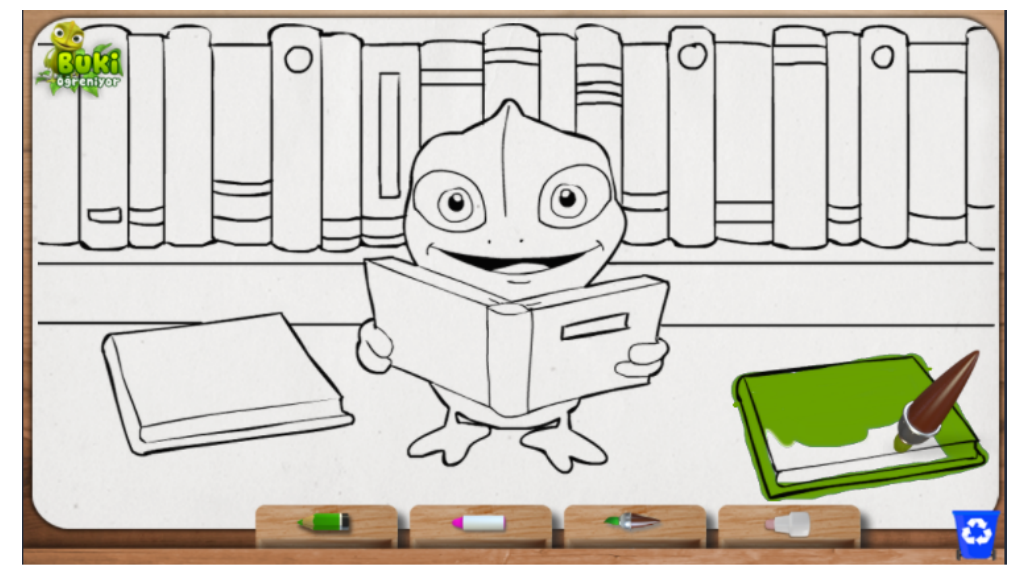

Görsel 5. EBA etkileşimli boyama etkinliği: Buki kütüphanede

EBA ses dosyası (Podcast): Okul öncesi eğitim müzik ve Türkçe etkinlikleri kapsamında kullanılan ses dosyaları, öğrencilerin işitsel dikkat geliştirmelerini destekleyen içeriklerdir.

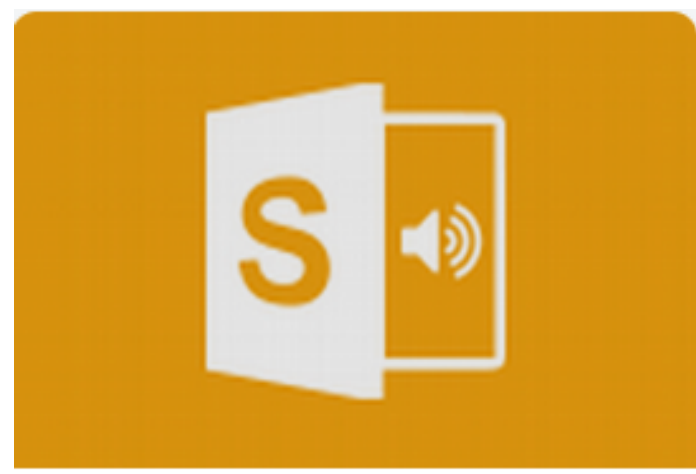

İzmir Oyun Müzikleri - 1

Kütüphane/Kültür ve Sanat/Dramatik

(Sahne) Sanatları/Halk Oyunları

Görsel 6. EBA ses dosyası. İzmir oyun müzikleri

\section{Çalışmayla Doğrudan İlişkisi Olmayan Araştırmalar}

$\mathrm{Bu}$ bölümde görsel okuryazarlık kavramının özel bir gelişim dönemi ile sınırlandırılmadan, temel kavramlar ve bileşenler çerçevesinde yapılandırıldı̆̆ araştırmalar incelenmiştir. $\mathrm{Bu}$ araştırmalardan elde edilen bilgi, okul öncesi dönem çocuklarının görsel okuryazarlık düzeylerinin daha net anlaşılabilmesi için öncül durumdaki bilgi olarak değerlendirilebilir.

Bilginin kayda alınmasının ve aktarılmasının tarihsel sürecinde yazıdan önce kullanılan resimler ve semboller, zaman ilerledikçe harflere dönüşüp alfabeyi oluşturmuş ve sözel iletişimin temel kaynağı ortaya çıkmıştır. Bu gerçek, görsel algı ve dil gelişimi arasındaki 
yakın ve zorunlu ilişkiyi ortaya koymaktadır. Yine de sözel iletişim, görsel iletişimin varlığını ve önemini değiştirmemiş; iki iletişim türü de başlangıçlarından günümüze kadar özgün kurallarını ve değerlerini sürdürmüştür. Duygu ve düşünceler bir şair tarafından sözcüklerle, bir ressam tarafından ise görsel dilde ifade edilmektedir. Sözel ve görsel iletişim karşılaştırmasında birinin diğerinden üstün veya eksik olduğu sonucuna ulaşılamaz. Bu iki iletişim türü birbirlerinden ayrılmayan ve birbirlerini destekleyen bir bağl1lık göstermektedir. Resimli sözlükler ve kitaplar bu işbirliğinin örnekleridir (İşler, 2002, s.155-156).

Görsel okuryazarlık, okuma ve yazma kavramlarına işaret ederken bireyin hem etken hem de edilgen olduğu iki duruma dikkat çekmektedir. Okuma eylemi "anlama, anlamlandırma, kavrama" gibi bireysel-bilişsel aktivitelerimizi işaret ederken yazma eylemi “anlatma, ifade etme, yorumlama, özetleme, dönüştürme, yaratma” gibi ve kendi dışımızdaki dünyayla iletişimimizin kapsamında yer alan bilişsel / sosyal / dilsel aktivitelerimizi hedef alır. O halde bilgi okuryazarlığı kavramını tanımlarken bu iki boyutu göz önünde bulundurmak gerekmektedir.

Debes ve arkadaşları tarafından 1969 yılında kurulan Uluslararası Görsel Okuryazarlık Derneği (International Visual Literacy Association - IVLA), alandaki çalışmalar için önemli başlangıç noktası olmuştur. Debes, görsel okuma kavramını ilk kez ifade eden kişi olarak yaptığı tanımda "insanın var olan algılama deneyimleriyle bütünleştirdiği ve geliştirilebilecek görme yetileri” ifadesini kullanmıştır. Debes' in tanımı görsellerle ilgili olarak yalnız algılama boyutunu vurgulamıştır; görsel üretme boyutu tanımın kapsamında değildir (Akt. Tüzel, 2010, s.693).

Wileman, görsel okuryazarlık kavramını "fotografik / grafik görüntülerin ilettiği bilgileri okuma, yorumlama ve anlama yetisi” olarak tanımlamıştır. Bu bağlamda görsel düşünme kavramını da "iletişime yardımcı olan resim, grafik ve diğer formlardaki tüm enformasyonu bilgiye dönüştürmek" olarak açıklamıştır (Akt. Stokes, 2002, s.12).

1969-2013 yılları arasında yayımlanmış on bir adet görsel okuryazarlık tanımının incelenmesi ile görsel okuryazarlık becerileri; görsel okuma, görsel yazma ve diğer görsel okuryazarlık becerileri olmak üzere üç bölümde gruplanmıştır (Kedra, 2018, s.81). 


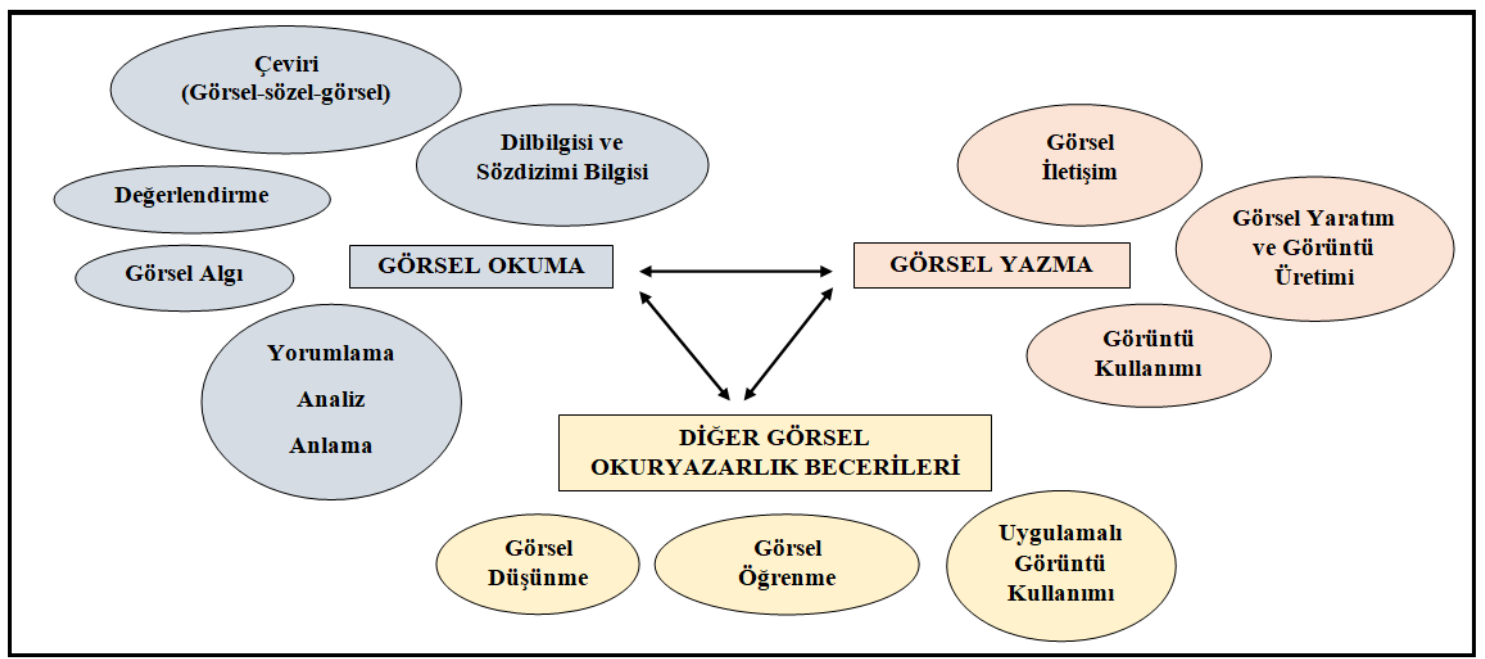

Şekil 1. Tematik gruplama ile görsel okuryazarlığın 3 kategorisi

Görsel okuma: En yalın ifadeyle bireylerin çevrelerin gördükleri her türlü nesne ve durumu analiz edebilmelerini sağlayan yetenekler olarak tanımlanmış olan görsel okuma (Stokes, 2005);

- Yazılı metinler içinde bulunmayan görsel öğeleri,

- Resim ve grafik türündeki iletileri,

- Doğadaki olayların meydana geliş şeklinin ve durumlar arasındaki neden-sonuç ilişskisini,

- Gözle izlenebilen tüm olguları anlama, analiz etme, değerlendirme, yorumlama yeteneklerini ifade eder (Akt. Sarıkaya, 2017, s.780).

Görsel yazma: Bireylerin gözle görülebilen her türlü iletiyi -metin, resim, çizim, grafik, fotoğraf, video, sunu vb.- oluşturma, üretme, düzenleme yeteneklerinin tamamıdır.

Görsel düşünme: Soyut kavramların, metinlerin, olayların, kalıcı hafızaya geçirilmesi; hedeflenen bilgilerin, beynin sağ yarısının aktif kullanımıyla canlı, gerçekçi, kalıcı ve tanıdık bilgilere dönüştürülerek kodlanması yeteneğidir. $\mathrm{Bu}$ yeteneklerini geliştiren bireyler görsel çevrelerini daha iyi anlar ve yorumlar, bilgiyi farklı biçimlerde işleme yeteneği kazanırlar ve farklı bakış açıları geliştirmede ustalaşırlar (Tüzel, 2010, s.699).

Görsel öğrenme: Bilgi edinme sürecinde verimli etkiye sahip olan görsel öğrenme, görsel düşünme sonucunda oluşur. Görsel bilginin nasıl yorumlanacağı ve kullanılacağ1 hakkında bilgi ve yetkinlik kazanmış olan birey, kendi öğrenme tercihlerine en uygun görsel bilgiyi kullanarak öğrenme kapasitesinin artırır. 


\section{Yöntem}

\section{Araştırma Modeli}

Bilimsel araştırmalarda tarama modelleri, geçmişte veya içinde bulunulan zamanda var olan belli bir durumu mevcut şekliyle betimlemenin amaçlandığı yaklaşımlardır. İlişkisel tarama modeli ise İki ya da daha fazla sayıdaki değişken arasındaki karşılıklı ilişkinin derecesini belirlemenin amaçlandığ 1 ve tarama modelinin bir türü olarak kullanılan modeldir (Karasar, 2000, s.77-81). Araştırmada betimsel yaklaşım çerçevesinde ilişkisel tarama modeli kullanılmıştır. Alanyazın taraması ve enformasyon incelemesi yapılarak konu ile ilgili mevcut duruma dair bir betimleme yapabilmek amaçlanmıştır. Okul öncesi dönemdeki 5-6 yaş çocuklarının görsel okuryazarlık durumları ve dijital öğrenme içerikleri ile çocuklar arasındaki ilgisel-motivasyonel ilişki üzerine inceleme yapmayı amaçlayan bu araştırmada verilerin toplanması, analizi ve yorumlanması aşamalarında nitel araştırma yöntemi kullanılmıştır.

\section{Araştırma Alanı ve Katılımcılar}

Araştırmanın evrenini, 2020-2021 Eğitim - Öğretim yılında Aydın ili Kuşadası ilçesi okul öncesi eğitim kurumlarına uzaktan eğitim sürecinde devam eden 5-6 yaş çocukları ve ebeveynleri oluşturmuştur. Katılımcılar seçilirken amaçlı örnekleme yöntemi türlerinden tipik durum örneklemesi kullanılmıştır. Tipik durum örneklemesinde araştırmacı seçtiği bir yeni uygulama ya da yeniliği tanıtmak amacıyla uygulama ya da yenilikle ilgili bir durum dizisi içinden en özgün bir veya birkaçını tespit ederek üzerinde çalışır (Patton, 1987). Bu örneklem yöntemiyle yeni bir uygulama olan okul öncesi uzaktan öğretim sürecini tanıtmak hedeflenmiş ve bu süreçteki durum araştırma konusuna göre sınırlandırılarak incelenmiştir.

Örneklem oluşturulurken ilçede görev yapan okul öncesi öğretmenleri aracılığıyla uzaktan eğitim çalışmalarında aktif olan 5-6 yaş çocuklarının ailelerine araştırma bilgisi ulaştırılmış ve katılımları isteğe bağlı olarak gerçekleşmiştir. Google drive aracı ile elektronik ortamda iletilen ankete gönüllülük esasına göre toplamda 85 ebeveyn katılmıştır. Araştırmanın örneklemine ait demografik özellikler şu şekildedir: 


\begin{tabular}{|c|c|c|c|}
\hline $\begin{array}{l}\text { Tablo } 2 \\
\text { 5-6 Yaş Çocukl } \\
\text { Düzeyini Belirle } \\
\text { Özelliklerinin D }\end{array}$ & $\begin{array}{l}\text { Dijital Öğrenme Içerikl } \\
\text { actyla Uygulanan Ank }\end{array}$ & $\begin{array}{l}\text { Motiv } \\
\text { Den }\end{array}$ & \\
\hline Değişkenler & Alt Kategoriler & $\mathbf{n}$ & $\%$ \\
\hline Cinsiyet & Kadın & 76 & 89,4 \\
\hline & Erkek & 9 & 10,6 \\
\hline Medeni Durum & Evli & 74 & 87,1 \\
\hline & Bekar & 11 & 12,9 \\
\hline Yaş & $24-34$ & 29 & 34,1 \\
\hline & $35-45$ & 46 & 54,1 \\
\hline & $46-56$ & 10 & 11,8 \\
\hline & 57 ve üstü & - & - \\
\hline Öğrenim Durumu & Okuryazar & - & - \\
\hline & İlkokulu & 2 & 2,4 \\
\hline & İlköğretim ya da ortaokul & 10 & 11,8 \\
\hline & Lise & 11 & 12,9 \\
\hline & Önlisans & 2 & 2,4 \\
\hline & Lisans & 44 & 51,8 \\
\hline & Yüksek Lisans & 15 & 17,6 \\
\hline & Doktora & 1 & 1,2 \\
\hline
\end{tabular}

Çalışmaya 76'sı kadın ve 9'u erkek olmak üzere toplam 85 ebeveyn katılmıştır. Katılımcı grubunun çoğunluğunun bayan ve evli olduğu, ayrıca katılımcı grubunun öğrenim seviyesinin yüksek olduğu görülmektedir. Ön lisans, lisans, yüksek lisans ve doktora mezunu olarak beyanda bulunan toplam kişi sayısı 62' dir ve katılımcı grubunun \% 72,9'unu oluşturmaktadır.

\section{Veri Toplama Araçları}

Araştırma sürecinde verilerin toplanmasında araç olarak Google drive-anket uygulaması ile hazırlanan "5-6 Yaş Çocuklarının Dijital Öğrenme İçeriklerine Gösterdiği İlgi ve Motivasyon Düzeyini Belirleme” formu kullanılmıştır. Uzaktan öğretim faaliyetleri sürecinde çocukları ile ilgili gözlemlerini ölçüt alan ebeveynler, verilen cümleleri “(1) Kesinlikle Katılmıyorum, (2) Katılmıyorum, (3) Kararsızım, (4) Katılıyorum, (5) Kesinlikle Katıllyorum" seçeneklerinden sadece bir tanesini işaretleyerek değerlendirmişlerdir. Bu formda kullanılan araştırma önermeleri şunlardır:

1. Okul öncesi eğitimde kullanılan EBA dijital kitap içeriği, çocuğumun ilgi ve motivasyonla yararlandığg bir öğrenme materyalidir.

2. Okul öncesi eğitimde kullanılan EBA eğitici çizgi film içeriği, çocuğumun ilgi ve motivasyonla yararlandığ 1 bir öğrenme materyalidir.

3. Okul öncesi eğitimde kullanılan EBA konu anlatımlı video içeriği, çocuğumun ilgi ve motivasyonla yararlandığı bir öğrenme materyalidir. 
4. Okul öncesi eğitimde kullanılan EBA doküman (pdf) içeriği, çocuğumun ilgi ve motivasyonla yararlandı̆̆

5. Okul öncesi eğitimde kullanılan EBA etkileşimli içerikler (boyama, interaktif oyun, yapboz), çocuğumun ilgi ve motivasyonla yararlandığı bir öğrenme materyalidir.

6. Okul öncesi eğitimde kullanılan EBA ses dosyası (podcast) içeriği, çocuğumun ilgi ve motivasyonla yararlandığı bir öğrenme materyalidir.

\section{Veri Toplama Süreci}

Araştırma verileri, 2020-2021 Eğitim - Öğretim yılının ikinci dönemimde, Aydın ili Kuşadası İlçesi’nde toplanmıştır. Araştırma anketi, Milli Eğitim Bakanlığında görev yapan okul öncesi öğretmenleri aracılığıyla okul öncesi eğitim kurumlarına uzaktan eğitim sürecinde devam eden 5-6 yaş çocukların ebeveynlerine iletilmiştir. Araştırmaya gönüllü olarak 85 ebeveyn katılmıştır.

\section{Veri Analizi}

Araştırmada katılımcılara yönlendirilen araştırma sorularının cevapları, araştırmada belirlenen ana temalar çerçevesinde incelenmiş ve elde edilen bulgular değerlendirilmiştir. Sayısal verilere göre oluşturulan grafikler, alanyazındaki araştırma sonuçlarıyla karşılaştırılmış ve bulgular yorumlanmıştır.

\section{Araştırmanın İnanırı̆̆g}

Araştırmanın inanırlığını sağlamak amacıyla veri sağlama, araştırmacı sağlama ve yöntem sağlama yöntemleri seçilmiştir. Uygulama sürecinde araştırmacıyla aynı ilçedeki okul öncesi öğretim kurumlarında görev yapmakta olan öğretmen ve yöneticiler, katılımcı gruba araştırma bilgilerini iletme ve destek olma görevini üstlenmişlerdir. Araştırma sürecine gönüllü olarak katılan bu uzman eğitimciler, okul öncesi uzaktan eğitim uygulamalarındaki deneyim ve bilgileriyle araştırmanın inanırlığını güçlendirmişlerdir.

\section{Etik Konular}

Çalışmada araştırmacı sorumluluğu ve katılımcı hakları olarak değerlendirilecek etik konular kapsamında dikkatli ve özenli davranılmıştır. Araştırmacı katılımcılara ulaşırken resmi ve gerçek iletişim kanalları kullanmış, katılımcılara çalışmanın öneminin ve çalışmadaki rollerinin anlatılmasında konu uzmanlarının desteğini almıştır. Ayrıca araştırmacı üzerinde değiştirme yapılamayacak olan, verileri hatasız biçimde görmeyi mümkün ve verilerin süresiz olarak saklanabilmesini sağlayan bir ölçme ortamı (bulut) kullanmıştır. Katılımcılar gönüllülük çerçevesinde araştırmaya davet edilmiş, katılımcı 
kimliklerinin gizli tutulacağı kendilerine bildirilmiş ve araştırma sonuçlarını yine aynı iletişim kanallarıyla katılımcılara iletilmiştir.

\section{Araştırmanın Güçlü Sınırlı Yönleri}

Araştırmada betimsel yaklaşım çerçevesinde ilişkisel tarama modeli kullanılmıştır. 2012 yılından itibaren örgün eğitimdeki okul öncesi uzaktan eğitim uygulamalarında EBA öğrenme platformunun kullanılıyor olması, öğrenen ve öğrenme içeriği arasındaki etkileşimin gözlenebilirliğini kolaylaştırmış ve bu durum araştırmanın en güçlü yönünü oluşturmuştur. Araştırma sorularının uzaktan eğitim sürecindeki 5-6 yaş çocuklarının ebeveynlerinin gerçek gözlemlerine ve çocukların özgür beyanlarına göre değerlendirilmesi, araştırmanın güçlü yönleri arasındadır. Katılımcıların sınırlı bir coğrafyadan araştırmaya dahil olması ve 85 gönüllü katılımcı ile sürdürülmüş olması ise araştırmanın sınırlı yönlerinin oluşturmaktadır.

\section{Bulgular ve Yorumlar}

Araştırmanın birinci alt problemi olan “(Okul Öncesi Eğitimde EBA öğrenme platformunda kullanılan) dijital kitap içeriği çocuğumun ilgi ve motivasyonla yararlandığı bir öğrenme materyalidir.” sorusuna yönelik elde edilen bulgular Grafik 1'de gösterilmiştir.

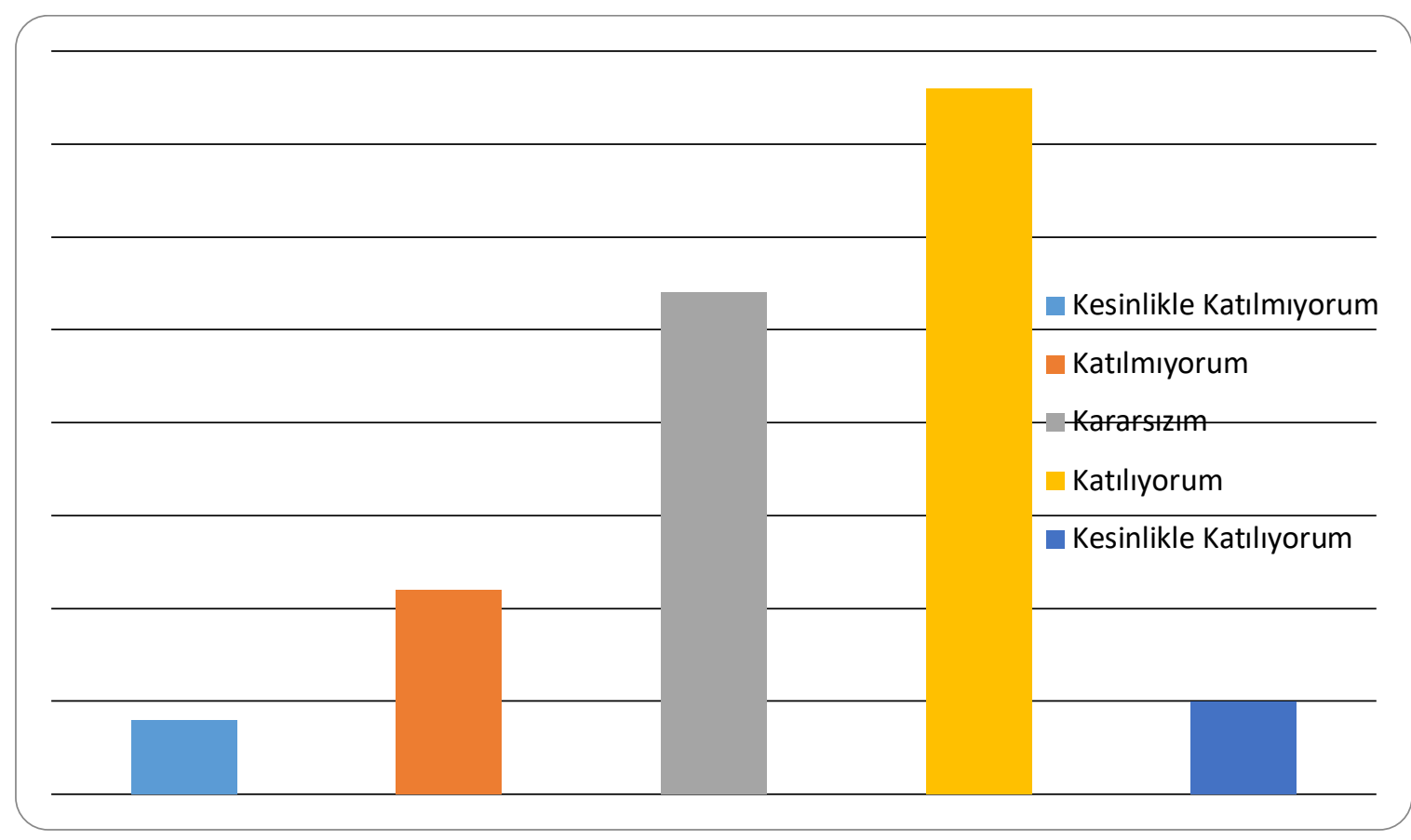

Grafik 1. Ebeveynlerin “ (Okul Öncesi Eğitimde EBA öğrenme platformunda kullanılan) dijital kitap içeriği çocuğumun ilgi ve motivasyonla yararlandığı bir öğrenme materyalidir” sorusuna verdikleri cevapların betimsel analizi. 
Grafik 1'de belirtildiği gibi birinci alt problemle ilişkili olarak çalışmaya katılan 85 ebeveynden 4'ü (\% 4,7) kesinlikle katılmıyorum, 11'i (\% 12,9) katılmıyorum, 27'si (\% 31,8) kararsızım, 38'i (\% 44,7) katılıyorum ve 5'i (\% 5,9) kesinlikle katılıyorum cevabını vermiştir. Olumlu cevap veren katılımcı sayısı 43 'tür $(\% 50,6)$.

Araştırmanın ikinci alt problemi olan “(Okul Öncesi Eğitimde EBA öğrenme platformunda kullanılan) eğitici çizgi film içeriği, çocuğumun ilgi ve motivasyonla yararlandığı bir öğrenme materyalidir.” sorusuna yönelik elde edilen bulgular Grafik 2'de gösterilmiştir.

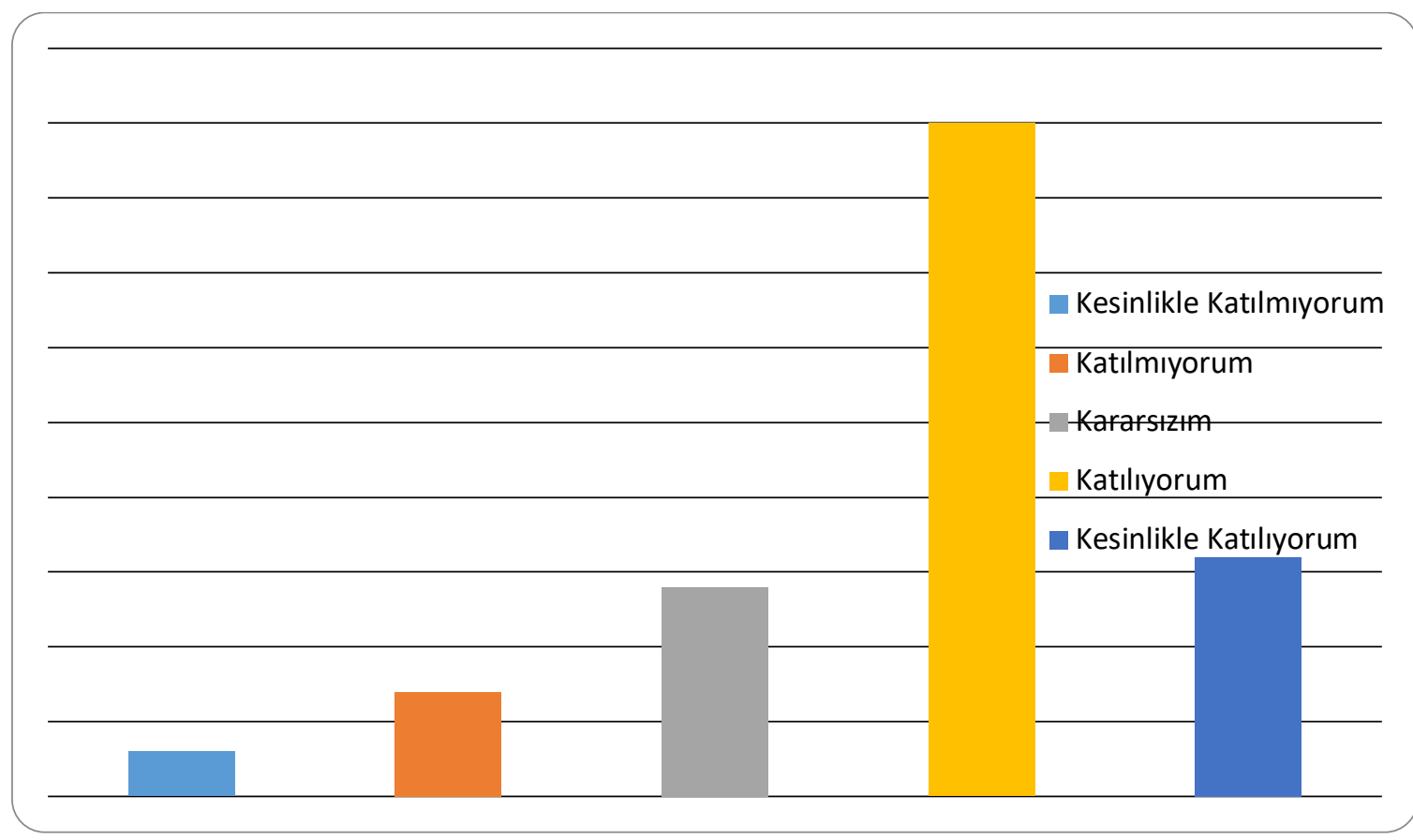

Grafik 2. Ebeveynlerin “(Okul Öncesi Eğitimde EBA öğrenme platformunda kullanılan) eğitici çizgi film içeriği çocuğumun ilgi ve motivasyonla yararlandığı bir öğrenme materyalidir" sorusuna verdikleri cevapların betimsel analizi.

Grafik 2'de belirtildiği gibi ikinci alt problemle ilişkili olarak çalışmaya katılan 85 ebeveynden 3'ü (\% 3,5) kesinlikle katılmıyorum, 7'si (\% 8,2) katılmıyorum, 14'ü $(\%$ 16,5) kararsızım, 45'i (\% 52,9) katılıyorum ve 16'sı (\% 18,8) kesinlikle katılıyorum cevabını vermiştir. Olumlu cevap veren katılımcı sayısı 61 'dir (\% 71,7).

Araştırmanın üçüncü alt problemi olan “ (Okul Öncesi Eğitimde EBA öğrenme platformunda kullanılan) konu anlatımlı video içeriği, çocuğumun ilgi ve motivasyonla 
yararlandığı bir öğrenme materyalidir." sorusuna yönelik elde edilen bulgular Grafik 3'te gösterilmiştir.

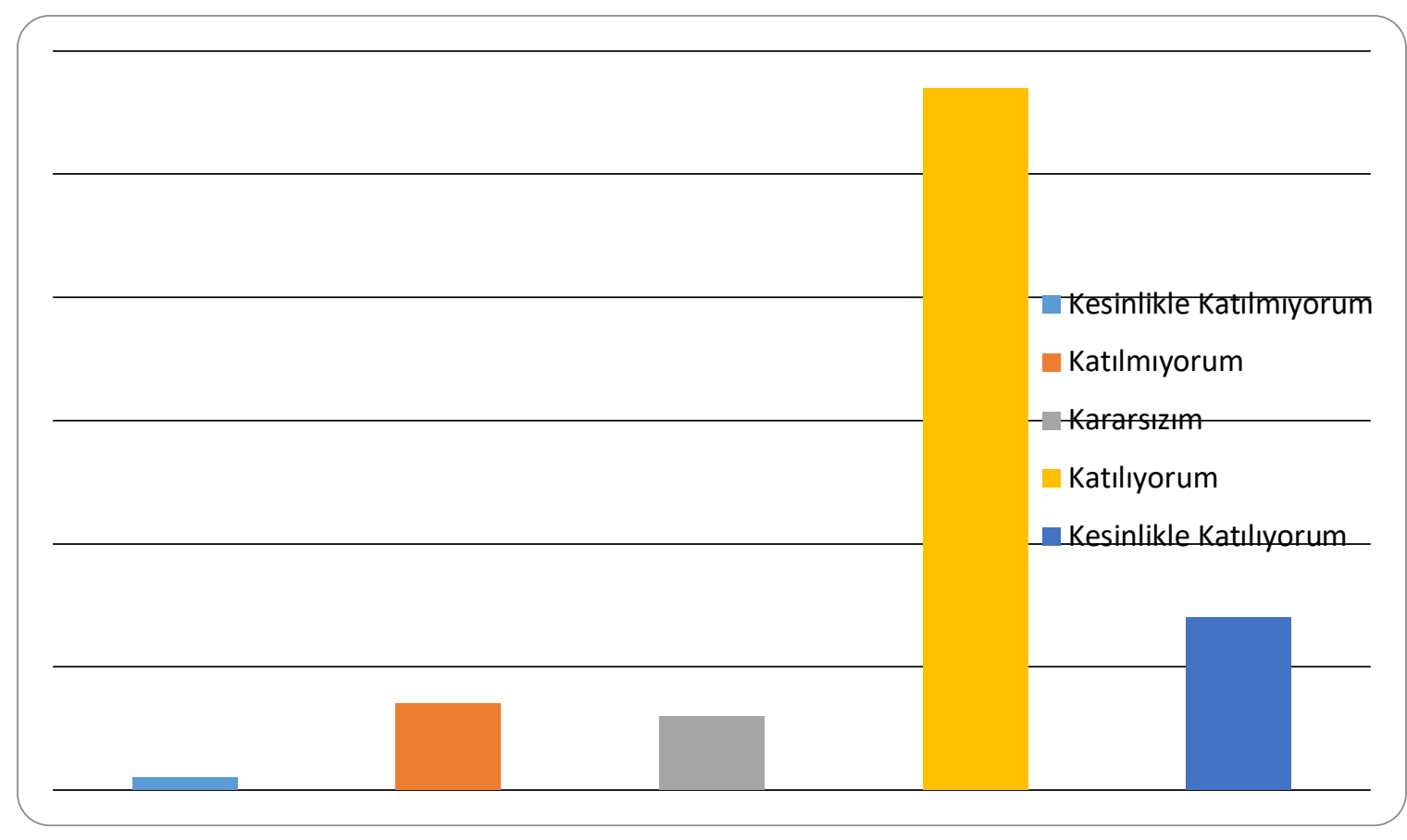

Grafik 3. Ebeveynlerin “ (Okul Öncesi Eğitimde EBA öğrenme platformunda kullanılan) konu anlatımlı video içeriği çocuğumun ilgi ve motivasyonla yararlandığı bir öğrenme materyalidir" sorusuna verdikleri cevapların betimsel analizi.

Grafik 3'te belirtildiği gibi üçüncü alt problemle ilişkili olarak çalışmaya katılan 85 ebeveynden 1'i (\% 1,2) kesinlikle katılmiyorum, 7'si (\% 8,2) katılmiyorum, 6's1 (\% 7,1) kararsızım, 57'si (\% 67,1) katılıyorum ve 14'ü (\% 16,5) kesinlikle katılıyorum cevabını vermiştir. Olumlu cevap veren katılımcı sayısı 71 'dir (\% 83,5).

Araştırmanın dördüncü alt problemi olan “ (Okul Öncesi Eğitimde EBA öğrenme platformunda kullanılan) doküman (pdf) içeriği, çocuğumun ilgi ve motivasyonla yararlandığı bir öğrenme materyalidir.” sorusuna yönelik elde edilen bulgular Grafik 4'te gösterilmiştir. 


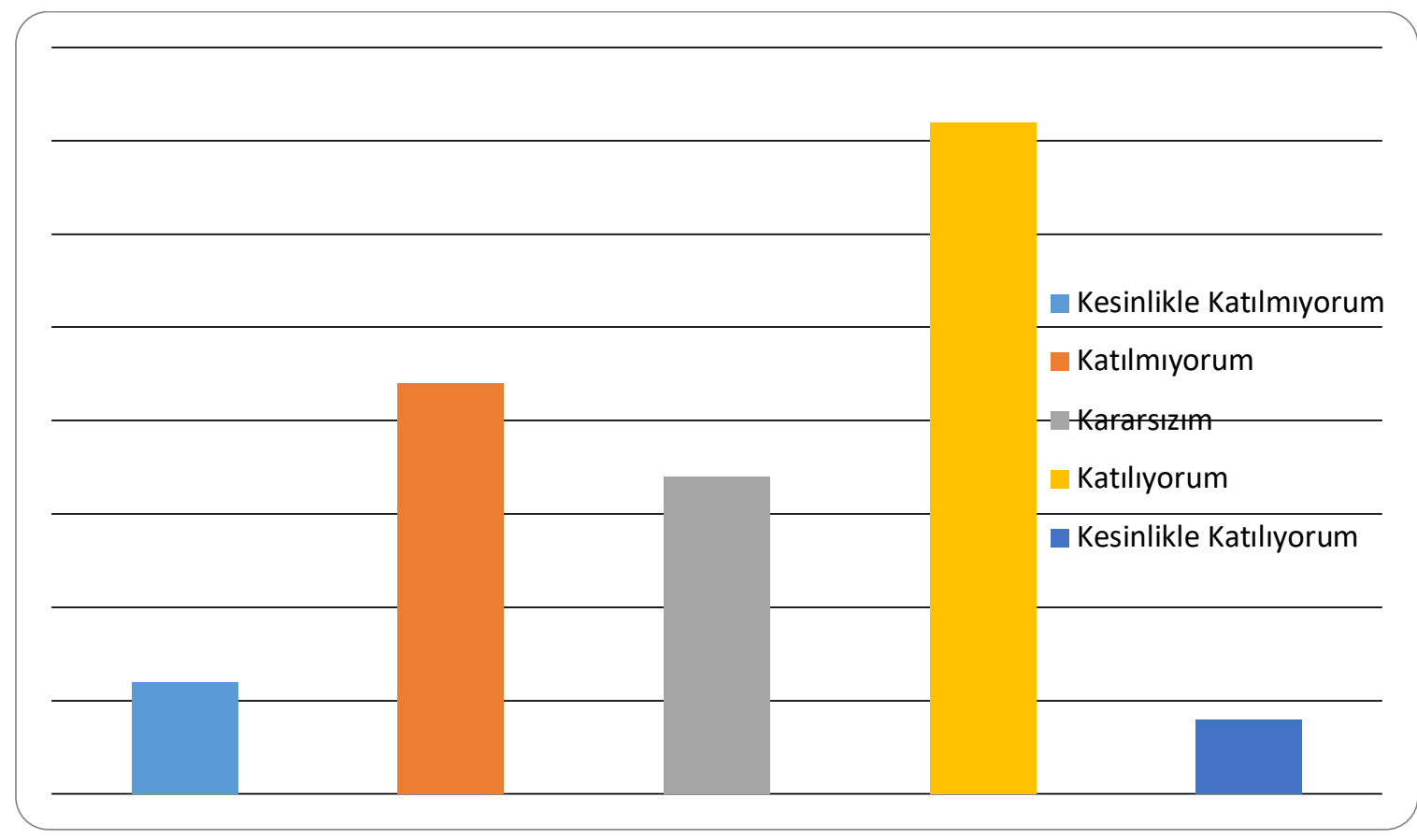

Grafik 4. Ebeveynlerin “ (Okul Öncesi Eğitimde EBA öğrenme platformunda kullanılan) doküman (pdf) içeriği çocuğumun ilgi ve motivasyonla yararlandığı bir öğrenme materyalidir" sorusuna verdikleri cevapların betimsel analizi.

Grafik 4'te belirtildiği gibi dördüncü alt problemle ilişkili olarak çalışmaya katılan 85 ebeveynden 6's1 (\% 7,1) kesinlikle katılmıyorum, 22'si (\% 25,9) katılmıorum, 17'si (\% 20) kararsızım, 36'sı (\% 42,4) katıllyorum ve 4'ü (\% 4,7) kesinlikle katılıorum cevabını vermiştir. Olumlu cevap veren katılımcı sayısı 40’tır (\% 47).

Araştırmanın beşinci alt problemi olan "(Okul Öncesi Eğitimde EBA öğrenme platformunda kullanılan) etkileşimli içerikler (boyama, interaktif oyun, yapboz) çocuğumun ilgi ve motivasyonla yararlandığı birer öğrenme materyalidir.” sorusuna yönelik elde edilen bulgular Grafik 5'te gösterilmiştir. 


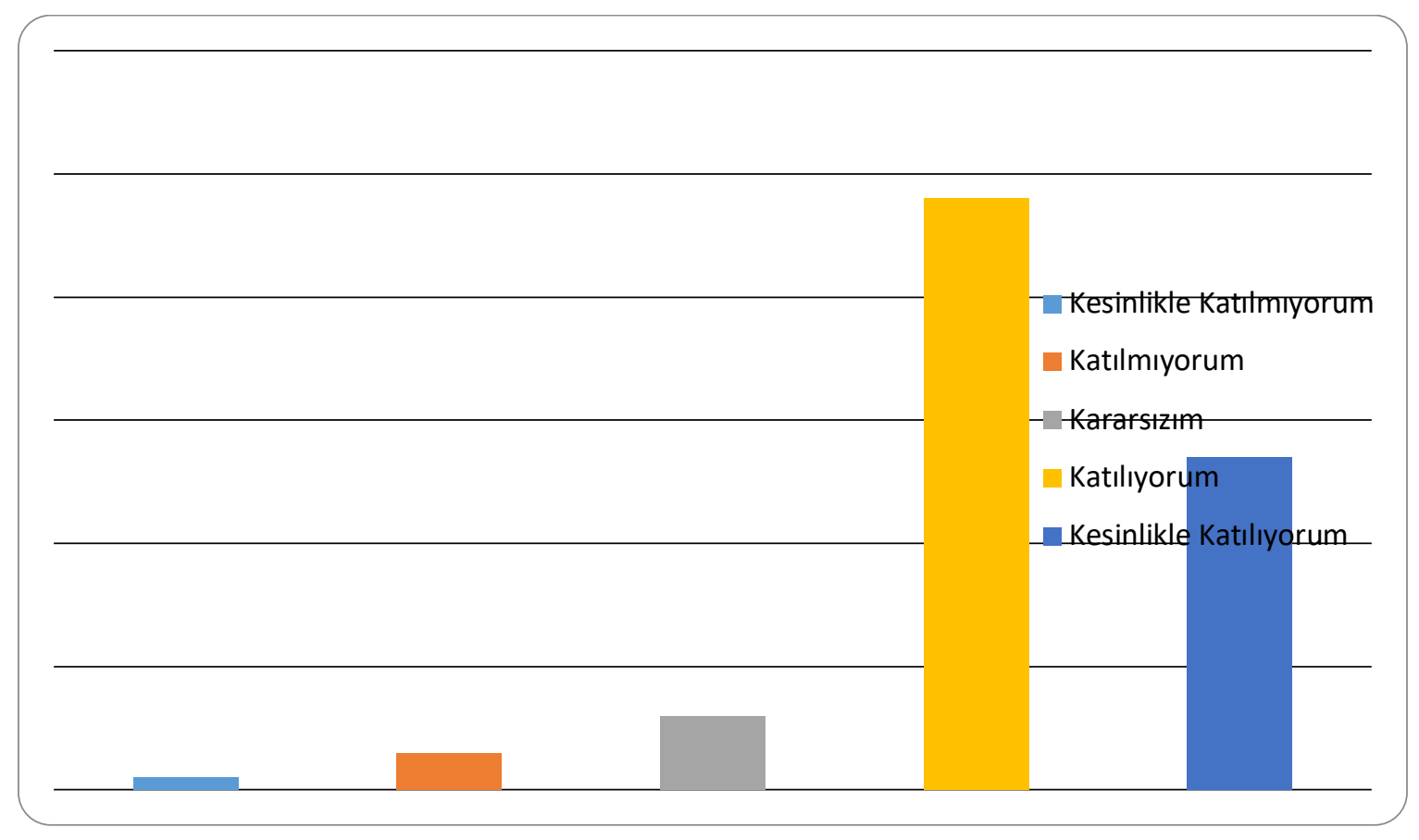

Grafik 5. Ebeveynlerin “ (Okul Öncesi Eğitimde EBA öğrenme platformunda kullanılan) etkileşimli içerikler (boyama, interaktif oyun, yapboz) çocuğumun ilgi ve motivasyonla yararlandığı birer öğrenme materyalidir” sorusuna verdikleri cevapların betimsel analizi.

Grafik 5'te belirtildiği gibi beşinci alt problemle ilişkili olarak çalışmaya katılan 85 ebeveynden 1'i (\% 1,2) kesinlikle katılmıorum, 3'ü (\% 3,5) katılmıyorum, 6'sı (\% 7,1) kararsızım, 48'i (\% 56,5) katılıyorum ve 27'si (\% 31,8) kesinlikle katılıyorum cevabını vermiştir. Olumlu cevap veren katılımcı sayısı 75 'tir $(\% 88,2)$.

Araştırmanın altıncı alt problemi olan “ (Okul Öncesi Eğitimde EBA öğrenme platformunda kullanılan) ses dosyası (Podcast) içeriği çocuğumun ilgi ve motivasyonla yararlandığı birer öğrenme materyalidir." sorusuna yönelik elde edilen bulgular Grafik 6'da gösterilmiştir. 


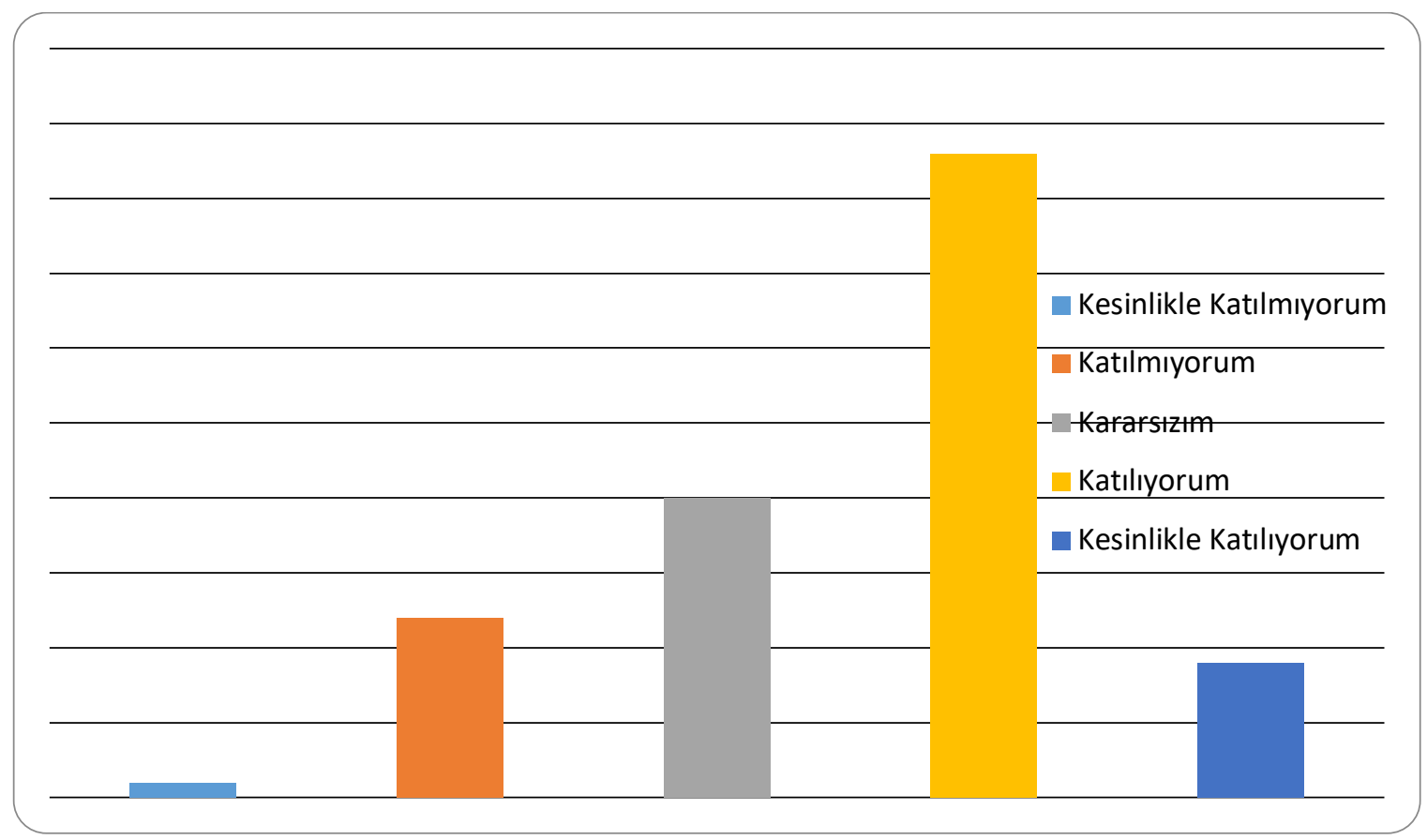

Grafik 6. Ebeveynlerin “ (Okul Öncesi Eğitimde EBA öğrenme platformunda kullanılan) ses dosyası (Podcast) içeriği çocuğumun ilgi ve motivasyonla yararlandığı birer öğrenme materyalidir" sorusuna verdikleri cevapların betimsel analizi.

Grafik 6'da belirtildiği gibi altıncı alt problemle ilişkili olarak çalışmaya katılan 85 ebeveynden 1'i (\% 1,2) kesinlikle katılmiyorum, 12'si (\% 14,1) katılmıorum, 20'si (\% 23,5) kararsızım, 43'ü (\% 50,6) katılıyorum ve 9'u (\% 10,6) kesinlikle katıliyorum cevabını vermiştir. Olumlu cevap veren katılımcı sayısı 52’dir (\% 61,2).

\section{Sonuç ve Tartışma}

Araştırmada (Okul Öncesi Eğitimde EBA öğrenme platformunda kullanılan) dijital kitap içeriğinin 5-6 yaş çocuklarında ilgi ve güdü sağlamadaki olumlu etkisinin $(\% 50,6)$ yüksek olduğu bulunmuştur. Dijital kitaplardaki metinlerin bir yetişkin tarafından ya da ses kaydı biçiminde okunmasının ve çocukların dikkatinin görsellere yönelmesinin, onların ilgi ve güdülerini aktif tuttuğu sonucuna ulaşılmıştır. $\mathrm{Bu}$ bulgu alanyazındaki araştırma sonuçlarıyla aynılık göstermektedir. Collen (2007) araştırmasında, sınıf içerisinde geleneksel hikaye saatinde hikayeyi dinlerken çocukların "kıpır kıpır okul öncesi hareketi” olarak adlandırdığı bir aktivite içinde oldukları ve okuma sırasında sayfadan uzağa / başka yöne baktıkları şeklindeki gözlemini açıklamış; aynı çocukların dijital hikaye okunurken bahsedilen davranışı ne derecede gösterdiklerine dair gözlemini önceki durumla karşılaştırmıştır. Araştırmada okul öncesi çocuklarının dijital hikaye ile etkileşimdeyken yarı 
yarıya daha az hareketlilik gösterdikleri, bunun yanında dijital hikayelere olan dikkat ve ilgilerinin geleneksel hikaye kitaplarına kıyasla daha yüksek olduğu sonucuna ulaşmıştır. Ayrıca çocukların dijital sayfalar arasındaki geçişi fark ettikleri / hatırlattıkları ve sayfa geçişlerini kendi kendilerine yapmayı istedikleri gözlenmiştir.

Araştırmada eğitici çizgi film içeriğinin 5-6 yaş çocuklarının ilgi ve güdülerini sağlamadaki olumlu etkisinin $(\%$ 71, 7) önemli ölçüde yüksek olduğu bulunmuştur. 5-6 yaş çocuklarının eğlendirici, hareketli, tempolu ve yaratıcı buldukları için çizgi filmleri beğendikleri yönündeki alanyazında yer alan araştırma sonuçları ile eşdeğer bir bulguya ulaşılması, bu öğrenme içeriğinin çocukların ilgi ve güdülerini önemli düzeyde aktif tuttuğunu göstermektedir. Karakaş (2012, s.3030) tarafından yapılan ve çizgi filmlerin 5-6 yaş çocuklarının anlama ve dinleme becerilerini geliştirmede oldukça etkili olduğunun savunulduğu araştırma, çocukların izledikleri çizgi filmlerle bağlantılı olaylar kurguladıklarını ve çizgi filmle ilgili savundukları düşünceleri coşkulu sözlerle ifade ettiklerini göstermektedir. Araştırmaya katılan okul öncesi öğretmenlerinin yüksek çoğunluğu, çizgi filmlerin özellikle dil gelişimini desteklediği ve okul öncesi eğitimde yararlar sağladığı yolunda görüş bildirmişlerdir. Bu sonuç, çizgi filmlerin okul öncesi çocukları tarafından yüksek ilgi ve güdüyle izlendiğini ortaya koymaktadır.

Araştırmada 5-6 yaş çocuklarının konu anlatımlı video türündeki öğrenme içerikleri ile onların ilgi ve güdüleri arasındaki ilişki olumlu ve yüksek olarak belirlenmiştir $(\% 83,5)$. Eğitsel konuların işleniş ve sunuş sürecinde videoların tercih edilmesinin uzaktan okul öncesi öğretim sürecinde etkili öğrenmeyi gerçekleştirmek için önemli olacağ 1 sonucuna ulaşılmıştır. Konuyla ilgili önceden yapılmış araştırmalarda okul öncesi dönem çocukları için eğitici ve konulu video içeriğinin sürekli olarak kullanıldı̆̆ı televizyon yayınlarının, farklı duyulara hitap etmesi yönüyle eğitimde uygun ve etkili bir araç olduğu belirtilmektedir. Bu uygulama, okul öncesi eğitimde bilişsel, sosyal, psikomotor ve dil gelişimi alanlarında çocuklara önemli katkılar sağlamaktadır. Ek olarak öğrenmenin eğlenceli bir hale dönüştüğü, gerçek hayatın sağlayamayacağı farklı ve etkili yaşantılar videoların gösterimiyle çocuklara sunulabilmektedir. Televizyon yayınlarının çocukların hayal gücü ve yaratıcılıkları üzerinde olumlu etkiye sahip olduğu Zimmerman ve diğerleri (2004) tarafından da araştırılmış ve ortaya konmuştur (Akt. Sayan, 2016, s.71).

Araştırmada bir öğrenme içeriği olarak dokümanlarla çalışan çocukların ilgi ve güdülerinin düşük olduğu belirlenmiştir (\% 47). Doküman içeriklerinin genellikle çocukların yetişkin desteğine bağımlı olduğu yazılı yönerge ve anlatım içermesi, ödev niteliğindeki 
çalışma sayfalarını kapsaması ve az resim içermesi nedeniyle çocukların ilgi ve güdülerini sağlamada etkili bir öğrenme aracı olmadığı düşüncesi bu bulguyla doğrulanmıştır. Buna karşıt olarak Connor, Morrison ve Slomonski (2006, s.667), çocukların çalışma sayfası olarak adlandırılan dokümanlar ile çalışmalarının olumlu etkisini savunmuşlardır. Onların araştırmasının temelleri incelendiğinde ise bu araştırmada ulaştığımız olumsuz sonucun aslında Connor ve arkadaşlarının savıyla tutarlı olduğu görülmektedir.

Connor ve diğerleri, okul öncesi öğrenme faaliyetlerini üçe ayırarak incelemişlerdir:

- Öğretmen tarafından yönlendirilen faaliyetler (TM: teacher managed).

- Öğretmen ve çocuk tarafından yönlendirilen faaliyetler (TCM: teacher-child managed).

- Çocuk tarafından yönlendirilen faaliyetler (CM: child managed)

Araştırmada, çocukların bağımsız olarak çalışma sayfalarını tamamlamaları veya okuma köşesinde bir iki çocuğun kitap incelemesi yapması gibi etkinlikler, çocuğun kendi ilgisini ve kontrolünü öğretmen desteği olmadan etkinleştirdiği öğrenme faaliyetleri olarak nitelendirilmektedir. Çocuk tarafından yönlendirilen çalışmalar, çocuğun kendi ilgi ve güdülerini hangi hedefe -öğretmen / arkadaş / grup / nesne vb. - yönelteceğine özgür olarak karar verdiği çalışmalardır. Bu ilgi eğer gruba yönlendirilmişse, etkinlik süreci çocukların iletişimini, yardımlaşmasını, bilgi alışverişlerini ve yaratıcılıklarını olumlu yönde etkilemektedir. Bu bağlamda doküman (çalışma sayfası) içeriğinin grup çalışmalarındaki olumlu etkisinin evde tek başına çalışan çocukta ortaya çıkmaması doğaldır. Bir başka deyişle bu araştırmanın tek başına doküman çalışması yapmanın çocukların ilgisini çekmediğini ortaya koyması ile Connor ve arkadaşlarının grup halinde yapılan çalışmaların çocukların ilgi ve güdülerini aktif tuttuğu şeklinde bir bulguyu ortaya koyması, iki araştırmanın birbirini destekler durumda olduğunu gösterir. Bu karşılaştırmayla, bir öğrenme içeriğinin grup halinde kullanılmasının o içeriğin etkinliğini artırdığı sonucuna da ulaşılmaktadır.

Araştırmada eğitim amaçlı kullanılan etkileşimli içeriklerin (boyama, interaktif oyun, yapboz) çocukların ilgi ve güdülerini sağlamada en etkili öğrenme içeriği olduğu sonucuna ulaşılmıştır (\% 88,2). Bu bulguyla, çocukların yetişkine bağımlı olmadan yararlandıkları, yönettikleri ve anında geri bildirim alarak etkileşim sağladıkları interaktif içeriklerin onların dikkat, ilgi ve güdülerini yüksek tutan en etkili öğrenme içerikleri olduğu sonucuna ulaşılmıştır. 
Kirkorian (2018), konuyla ilgili incelediği araştırmalarda etkileşimli dijital içeriklerdeki taklit, nesne bulma ve kelime öğrenmeyi içeren görevlerin küçük çocukların öğrenmelerini desteklediği sonucunu gördüğünü aktarmaktadır. Onun araştırmasındaki bulgulara göre etkileşimin çocukların öğrenmeleri üzerindeki etkisi, etkileşimli özelliklerin dikkati ilgili bilgilere ne ölçüde yönlendirdiğiyle ilişkilidir. Ayrıca okul öncesi dönemdeki büyük çocuklar (5-6 yaş), daha küçük yaştaki çocuklara göre etkileşimli video içeriklerini bilinçli ve kontrollü kullanmakta ve gelişigüzel ekrana dokunma davranışı göstermemektedirler (Kirkorian, 2018, s.211-212). Bu bulgu, 5-6 yaş çocuklarının etkileşimli içerikleri daha kontrollü ve dikkatli yönettikleri şeklinde yorumlanabilir ve bu araştırmada etkileşimli içerikler ile ilgili ulaşılan sonucu desteklemektedir.

Araştırmada, 5-6 yaş çocuklarının ses dosyası (Podcast) türündeki öğrenme içerikleri ile onların ilgi ve güdüleri arasındaki ilişki olumlu ve yüksek olarak belirlenmiştir $(\% 61,2)$. Özellikle okul öncesi eğitim müzik ve Türkçe etkinliklerinde kullanılan podcast içeriklerinin, öğrenme sürecinde etkili olduğu sonucuna ulaşılmıştır. Alanyazında Sharon ve John (2019, s.338), görseller eşliğinde verilen ses kayıtlarının okul öncesi eğitimde etkili olduğunu ortaya koymuşlardır. "Okul Öncesi Dönemdeki 5-6 Yaş Çocuklarının Görsel Okuryazarlık Durumlarının ve Dijital Öğrenme İçeriklerinin İncelenmesi” başlıklı araştırmada podcast içeriğiyle ilgili ulaşılan sonuç bu mevcut bulguyu desteklemektedir.

\section{Öneriler}

Okul öncesi uzaktan eğitim sürecinde çocukları bulundukları mekanda bedensel olarak aktif olmaya ve gerçek nesnelerle çalışmaya, araştırma ve deney yapmaya yönlendirecek etkinliklerin düzenlenmesi esas olmalıdır. Bu süreci renklendirmek ve desteklemek amacıyla dijital öğrenme materyallerinin doğru seçimi ve kullanımı önemlidir. $\mathrm{Bu}$ araştırmanın sonuçları 1şı̆̆ında okul öncesi uzaktan eğitim sürecinde etkili öğrenmeyi sağlamak amacıyla eğitimcilere verilebilecek öneriler şu şekildedir:

- Okul öncesi uzaktan eğitim sürecinde kullanılacak tüm öğrenme içerikleri ve materyalleri, çocukların gelişim özellikleri ve bireysel farklılıkları gözetilerek düzenlenmelidir.

- Okul öncesi uzaktan eğitim sürecinde dijital kitap içeriklerinin kullanımı, çocukların ilgi ve güdülerini sağlayarak öğrenmeyi destekleyecektir. Dijital kitabı kullanarak hikayeyi anlayan çocuklarla sonrasında hikaye hakkında sohbet etmek, onlara sorular sormak, hikayedeki bir görseli birkaç saniyeliğine gösterip görselle ilgili sorular 
sorarak dikkat çalışması yapmak gibi çalışmalarla çocukların diğer bireylerle etkileşime geçmesi ve öğrenme durumlarıyla ilgili geri dönüt almaları sağlanmalıdır.

- Okul öncesi uzaktan eğitim sürecinde eğitici çizgi film içeriklerinin kullanımı, çocukların ilgi ve güdülerini sağlayarak öğrenmeyi destekleyecektir. Özellikle problem çözümü ve mizah unsuru içeren türdeki kısa çizgi filmlerin seçimi yararlı olacaktır. İçeriğin seyredilmesinden önce verilecek bir dikkat yönergesi, çocukların ilgi ve güdülerini destekleyecektir. Örneğin, seyredilecek çizgi filmdeki kedi karakterinin ağaçtan nereye düştüğünü cevaplayacak çocuklara kalem hediye edileceği söylenerek başlanan bir izleme etkinliği; çocukların hoşuna gidecek, onların ilgi ve güdülerini artıracaktır.

- Okul öncesi uzaktan eğitim sürecinde konu anlatımlı video içeriklerinin kullanımı, çocukların ilgi ve güdülerini sağlayarak öğrenmeyi destekleyecektir. Özellikle toplumsal yaşamla ilgili ulaşılması zor deneyimleri konu alan videoların seçimi yararlı olacaktır. Anıtkabir'e henüz gidememiş olan çocuklara, Anıtkabir'e ait resmi sanal müze uygulamasını göstermek, hayvanların doğal yaşamları ile ilgili belgesel türündeki içeriklerden yararlanmak, kokpiti tanıtmak için Türk Hava Yolları'nın çocuklar için hazırladığı tanıtım videolarını paylaşmak gibi çalışmalar, çocukların eksik yaşantılarını tamamlamak için etkili ve değerli olacaktır.

- Okul öncesi uzaktan eğitim sürecinde doküman içeriklerinin kullanımı çocukların ilgi ve güdülerini sağlamada yetersiz kalabilmektedir. Dokümanların bol resimli ve etkileşimli olarak yeniden düzenlenmesi ya da öğretim sürecine oyunlaştırmanın dahil edilerek doküman çalışmalarının ödüllendirilmesi ve sürecin eğlenceli hale getirilmesi yararlı olacaktır.

- Okul öncesi uzaktan eğitim sürecinde etkileşimli içeriklerin (boyama, interaktif oyun, yapboz) kullanımı, çocukların ilgi ve güdülerini sağlayarak öğrenmeyi desteklemek amacıyla izlenecek en etkili yöntemdir. Çocukların gelişim özelliklerine uygun olarak seçilecek / tasarlanacak olan etkileşimli içerikler, gün içerisinde gerçekleştirmeleri istenen ödevler olarak yönlendirildiğinde toplam sürenin günde 1 saatten az olmasına dikkat edilmelidir. Böylelikle çocukların ekran bağımlılı̆̆ı geliştirmelerine engel olunmalidir.

- Okul öncesi uzaktan eğitim sürecinde ses dosyası (Podcast) içeriklerinin kullanımı çocukların ilgi ve güdülerini sağlayarak öğrenmeyi destekleyecektir. Özellikle Türkçe ve müzik etkinliklerinde kullanılan ses dosyalarının tek kanallı olarak sunulduğu yani 
sese eşlik eden görsel kullanılmadığı durumlarda, çocukların dikkat süreleri göz önünde bulundurulmalı ve mümkün olduğunca kısa süreli dinleme etkinlikleri planlanmalıdır. Yine dinleme öncesinde verilecek bir görev, onların ilgi ve güdülerini destekleyecektir. Örneğin, "Şimdi dinleyeceğimiz sohbette, kedi ve köpeğin neden birbirlerine küstüklerinin anlamaya çalışalım, dinleme etkinliği bitince bununla ilgili konuşacağız.” Şeklindeki yönergeler, 5-6 yaş çocuklarının dikkatlerini aktif tutacaktır. 


\section{Kaynakça}

Ayhan, A. B., Mutlu, B., Aki, E. ve Aral, N. (2015). A study of conceptual development and visual perception in six-year-oldchildren. Perceptualand Motor Skills, 121(3), 832-839.

Bayır, E. ve Günşen, G. (2017). Okul öncesi dönem çocuklarının en çok izledikleri çizgi filmlerin bilimsel açılardan analizi. Trakya Üniversitesi Eğitim Fakültesi Dergisi, 7(2), 746-761.

Bilgin, H. (2011). 5-6 yaş çocuklarına yönelik 1990-2010 yılları arasında basılan resimli kitapların çocuğa görelik kavramına göre incelenmesi. Marmara Üniversitesi, Eğitim Bilimleri Enstitüsü. Yayınlanmamış Yüksek Lisans Tezi, İstanbul.

Bull, G. and Kajder, S. (2005). Digital storytelling in the language arts classroom. Learning \& Leading with Technology, 32(4), 46-49.

Ciğerci, F. M. (2015). Illkokul dördüncü sınıf Türkçe dersinde dinleme becerilerinin geliştirilmesinde dijital hikâyelerin kullanılması. Anadolu Üniversitesi, Eğitim Bilimleri Enstitüsü. Yayınlanmamış Doktora Tezi, Eskişehir.

Collen, L. (2007). The digital and traditional storytimes research project: Using digitized books for preschool group storytimes. World Libraries, 17(1).

Connor, C. M., Morrison, F. J. and Slominski, L. (2006). Preschool instruction and children's emergent literacy growth. Journal of Educational Psychology, 98(4), 665.

Flewitt, R. (2006). Using video to investigate preschool classroom interaction: Education research assumptions and methodological practices. Visual Communication, 5(1), 2550.

Güven, N. ve Bal, S. (2000). Dil gelişimi ve eğitimi. 0-6 yaş dönemindeki çocuklar için destekleyici etkinlikler. (1. Bask1). İstanbul: Epsilon.

İnan, H. (2020). Covid-19 pandemi sürecinde okul öncesi eğitimin yeniden yapılandırılması. Milli Eğitim Dergisi, Salgın Sürecinde Türkiye'de ve Dünyada Ĕ̈itim, 49(1), 831-849. 
İşler, A. Ş. (2002). Günümüzde görsel okuryazarlık ve görsel okuryazarlık eğitimi. Uludă̆ Üniversitesi Ĕ̆itim Fakültesi Dergisi, 15 (1), 153-161.

Karakaş, R. (2012). Theuse of cartoons for developing the skills of understanding and analyzing of children in preschool period. Procedia-Social and Behavioral Sciences, 46, 3026-3030.

Karasar, N. (2000). Bilimsel araştırma yöntemi. (10. bask1). Ankara: Nobel.

Kędra, J. (2018). What does it mean to be visually literate? Examination of visual literacy definitions in a context of Higher education. Journal of Visual Literacy, 37(2), 67-84.

Kirkorian, H. L. (2018). When and how do interactive digital media help children connect what they see on and off the screen?. Child Development Perspectives, 12(3), 210214.

Milli Eğitim Bakanlığı. (2013). Çocuk gelişimi ve eğitimi: Sosyal gelişim. Ankara: Milli Eğitim Yayınları.

Milli Eğitim Bakanlı̆̆ı. (2013). Okul öncesi eğitim programı. Ankara: Temel Eğitim Genel Müdürlüğü.

Öcel, N. (2012). Tv çocuk programlarında biçim, içerik, işlev ve 5-14 yaşın program seçimi üzerine. İstanbul Üniversitesi İletişim Fakültesi Dergisi, o(11).

Özkubat, S. (2015). Görsel farkındalık eğitim programının 5-6 yaş çocuklarının görsel okuryazarlıklarına etkisinin incelenmesi. Yayımlanmamış Doktora Tezi. Ankara: Gazi Üniversitesi, Eğitim Bilimleri Enstitüsü.

Patton, M. Q. (1987). How to use qualitative methods in evaluation (No. 4). Sage.

Peters, K. M. and Blumberg, F. C. (2002). Cartoon violence: Is it as detrimental to preschoolers as we think?. Early Childhood Education Journal, 29(3), 143-148.

Pezdek, K. and Stevens, E. (1984). Children's memory for auditory and visual information on television. Developmental Psychology, 20(2), 212.

Sarıkaya, B. (2017). Türkçe öğretiminde görsel okuma. Anemon Muş Alparslan 
Üniversitesi Sosyal Bilimler Dergisi, 5(3), 779-796.

Sayan, H. (2016). Okul öncesi eğitimde teknoloji kullanımı. 21. Yüzyılda Eğitim Ve Toplum Ĕgitim Bilimleri ve Sosyal Araştırmalar Dergisi, 5(13), 67-83.

Sever, S. (2003). Çocuk ve edebiyat. (1. Bask1). Ankara: Kök.

Sharon, T. and John, N. A. (2019). Imagining an ideal podcast listener. Popular Communication, 17(4), 333-347.

Stokes, S. (2002). Visual literacy in teaching and learning: A literature perspective. Electronic Journal for the integration of Technology in Education, 1(1), 10-19.

Şenyurt, Ö. (2015). Türk ĕgitim sisteminde bilgi hizmetleri projeleri. http://www.openaccess.hacettepe.edu.tr:8080/xmlui/bitstream/handle/11655/11763/ 0-\%C5\%9Eenyurt-221-234.pdf? sequence $=1$ Erişim Tarihi: 20.03.2021.

Türe Köse, H. B. (2019). Okul öncesi dönem çocuklarında dijital hikâye anlatımının dinleme becerisine etkisi. Dumlupınar Üniversitesi, Eğitim Bilimleri Enstitüsü. Yayınlanmamış Yüksek Lisans Tezi, Kütahya.

Tüzel, A. G. M. S. (2010). Görsel okuryazarlık. Türklük Bilimi Araştırmaları, 0(27), 691 705.

Varol, İ., Ala, S. ve Eti, M. (2020). Okul öncesi eğitimde Türkçe etkinliklerinde kullanılan hikâye anlatım tekniklerinin çocukların dikkat süresi üzerine etkisi. Temel Ĕ̈itim, 2(5), 26-39. 


\section{Yazarlar Hakkında}

\section{Nagihan ALPAY}

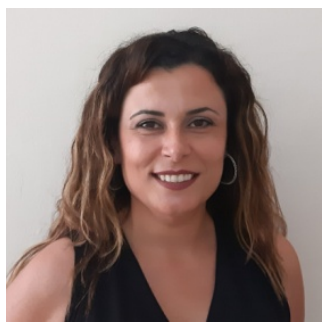

Nagihan ALPAY, lise öğrenimini İstanbul Pertevniyal Lisesi’nde (1994-1998) tamamlamış, ardından İzmir-Dokuz Eylül Üniversitesi Okul Öncesi Öğretmenliği bölümünü tamamlayarak 2002 yılında MEB' da okul öncesi öğretmeni olarak göreve başlamıştır. 2021 yılında “Anadolu Üniversitesi, Sosyal Bilimler Enstitüsü, Uzaktan Eğitim Anabilim Dalı, Uzaktan Öğretim Bilim Dalı (Online) Bölümünde yüksek lisans eğitimini tamamlamıştır. 2009 yılında Aydın İl Milli Eğitim

Müdürlüğü tarafından basılan Öykülerin Evrensel Dili (Universal Language of Stories) ile 2016 yılında basılan Okul Öncesinde Öğrenme Merkezleri ve Etkinlikleri isimli iki kitabı bulunmaktadır.

Posta adresi: Kuşadası İlkokulu, Kadınlar Denizi Mahallesi, 510 Sokak, No:4. Kuşadası / AYDIN Tel (İş): $\quad$ +90256 $\quad$ +90 $\quad$ +9223015

GSM: $\quad+905052517405$

Eposta: $\quad$ nagihanteacher@gmail.com

\section{Doç. Dr. Muhammet Recep OKUR}

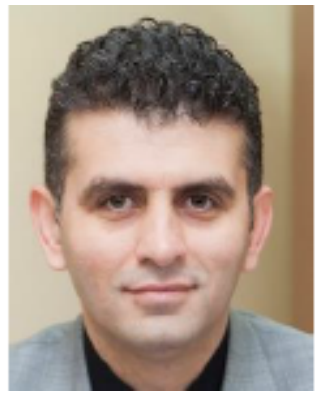

Doç. Dr. Muhammet Recep OKUR, lisans eğitimini Anadolu Üniversitesi Eğitim Fakültesi Bilgisayar ve Öğretim Teknolojileri Eğitimi Bölümünde 2002 yılında tamamlamıştır. Lisans eğitiminden sonra Anadolu Üniversitesi Fen Bilimleri Enstitüsü Bilgisayar Mühendisliği A.B.D. Bilişim Tezli Yüksek lisansını 2006 yılında tamamlamıştır. Eğitimine Anadolu Üniversitesi Sosyal Bilimler Enstitüsü Uzaktan Eğitim Anabilim Dalı Uzaktan Eğitim Bölümünde devam ederek 2012 yılında tamamlamış ve Dr. unvanı almıştır. 2017 yılında Açık ve Uzaktan Öğrenme alanında Doçent unvanı almıştır. 2002 yılında Anadolu Üniversitesi Açıköğretim Fakültesinde göreve başlamış ve halen çalışmalarına devam etmektedir. Öğrenen destek hizmetleri, e-öğrenme içerik üretimi, e-devlet yazarın çalışma alanları arasındadır.

Posta adresi: Anadolu Üniversitesi Yunus Emre kampüsü Açıköğretim Fakültesi Kat:7 No:702 Eskişehir Eposta:mrokur@gmail.com

Tel: 0222-3350580 